\title{
Sizing up the heart: development redux in disease
}

\author{
Eric N. Olson ${ }^{1,3}$ and Michael D. Schneider ${ }^{2}$ \\ ${ }^{1}$ Department of Molecular Biology, University of Texas Southwestern Medical Center, Dallas, Texas 75390-9148, USA; \\ ${ }^{2}$ Center for Cardiovascular Development, Departments of Medicine, Molecular and Cellular Biology, and Molecular \\ Physiology \& Biophysics, Baylor College of Medicine, Houston, Texas 77030-3498, USA
}

Following gastrulation and establishment of the three embryonic germ layers, the first definitive organ to form in the embryo is the heart, whose morphogenesis, growth, and integrated function are essential to embryonic survival, even by midgestation. Abnormalities in heart development result in congenital heart disease, the most frequent form of birth defects in humans. At the opposite end of the temporal spectrum, adult cardiac disease is the most common cause of death in the industrialized world, with congestive heart failure and inadequate pump function the end result of diverse disorders intrinsic to cardiac muscle cells, cardiac valves, systemic blood pressure, and the coronary blood supply. Despite recent therapeutic advances and mechanical devices to sustain cardiac function, only a minority of heart failure patients lives longer than 5 yr. Death from heart disease therefore comprises an epidemic more prevalent than all cancers combined (Ries et al. 2003).

Recent studies have begun to reveal the cellular circuitry that controls cardiac growth during development and disease. Intriguingly, many of the molecules and mechanisms that regulate growth of the embryonic heart are redeployed in the adult heart in response to stress signals that provoke cardiac enlargement and heart failure. Thus, understanding the mechanisms involved in heart development promises to provide insights into the molecular basis for pathogenesis of the adult heart, as well as to reveal novel therapeutic targets. In this review, we consider three aspects of cardiac development with significant implications for adult heart disease: (1) normal growth during organogenesis, (2) a "fetal" cardiac gene program reactivated in hypertrophy, and (3) restorative growth by undifferentiated progenitor cells that have cardiogenic potential. Each of these aspects of cardiac growth could be, itself, the subject of an in-depth review. Our goal, however, is not to comprehensively review these areas, but to identify common themes in developmental biology that are reiterated in settings of abnormal growth and dysfunction of the adult heart. Al-

${ }^{3}$ Corresponding author.

E-MAIL eric.olson@utsouthwestern.edu; FAX (214) 648-1196.

Article published online ahead of print. Article and publication date are at http://www.genesdev.org/cgi/doi/10.1101/gad.1110103. though we focus on development and disease of the myocardium, many of the same principles of allometric growth and homeostasis apply to other organs whose structure and function are influenced by physiological and pathological signaling.

\section{Developmental growth of the heart}

\section{Specification of cardiac cell fate by extracellular cues}

Heart formation is initiated in vertebrate embryos soon after gastrulation when a population of cells in a region of anterior mesoderm known as the cardiac crescent (Fig. 1) adopts a cardiac fate in response to cues from adjacent endoderm (Olson 2001). Three families of peptide growth factors have been studied most intensely for their positive (and negative) effects on the establishment of cardiac cell identity. Bone morphogenetic proteins (BMPs), a subset of the transforming growth factor- $\beta$ (TGF $\beta$ ) superfamily (Zaffran and Frasch 2002; Schneider et al. 2003), promote cardiogenesis in vertebrate embryos (Fig. 2). Similarly, the Drosophila ortholog, decapentaplegic (Dpp), its receptors, and effector Smad transcription factors are essential for the formation of the dorsal vessel, the rudimentary heart-like organ in fruit flies. Equivalent effects have been shown in Xenopus and avian embryos or explants, using soluble inhibitors of the BMP ligand-receptor interaction such as noggin (Schultheiss et al. 1997), dominant-negative BMP receptors (Shi et al. 2000), or inhibitory Smads (Krishnan et al. 2001; Walters et al. 2001). BMPs also are required to generate cardiac muscle cells from mouse teratocarcinoma cells in culture (Monzen et al. 1999). In mice, mutations of certain $\mathrm{BMPs}$ or of any BMP receptor are lethal at gastrulation, obscuring the potential role of BMPs in cardiogenic specification, even though their later role in cardiac morphogenesis was made clear by a heart-specific deletion (Gaussin et al. 2002; Schneider et al. 2003). Notably, epiblast-specific deletion of the type IA BMP receptor is permissive for gastrulation but markedly impairs the inception of heart development (Miura et al. 2002).

Limited studies, chiefly in avians and zebrafish, suggest an analogous cardioinductive role for fibroblast growth factors (Lough et al. 1996; Barron et al. 2000; 

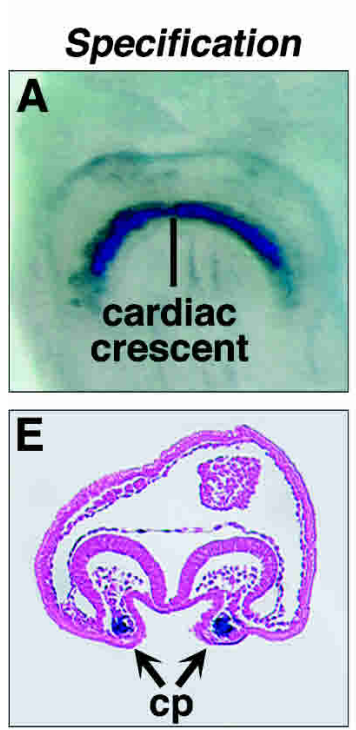

E7.75
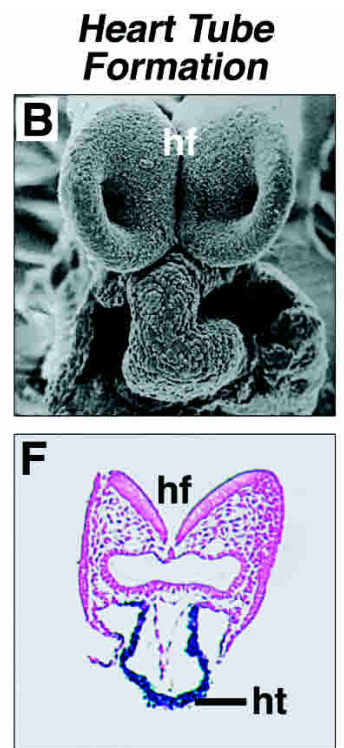

E8.0

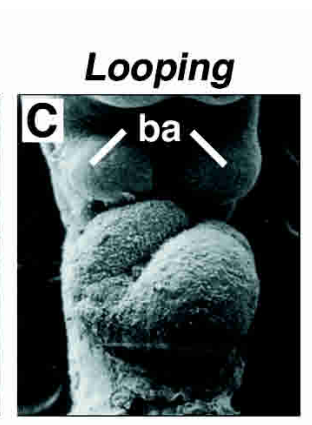

Chamber Growth and Maturation
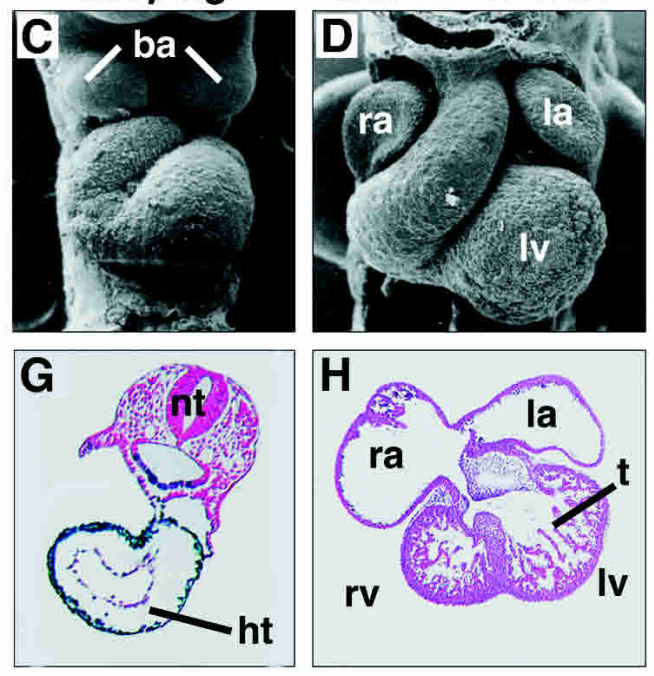

E9.5

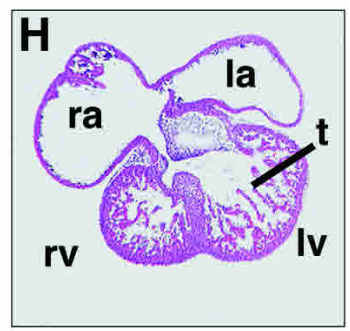

E12.0

Figure 1. Morphogenesis and growth of the heart. Stages in development of the mouse heart are shown. $(A)$ Expression in the cardiac crescent of a lacZ transgene linked to HAND2 regulatory sequences (McFadden et al. 2000). (E) A histological section. (B-D) Scanning electron micrographs of the developing heart. $(F, G)$ Histological sections of embryos harboring lacZ transgenes linked to the HAND2 and $N k x 2.5$ (Lien et al. 1999) regulatory sequences, respectively, at the indicated stages. The heart is indicated in blue. (ba) Branchial arch; (cp) cardiac progenitors; (hf) head folds; (ht) heart tube; (la) left atrium; (lv) left ventricle; (nt) neural tube; (ra) right atrium; (rv) right ventricle; $(\mathrm{t})$ trabeculae. (Panels $B-D$ are reprinted from Kaufman 1992 with permission from Elsevier.)

Reifers et al. 2000; Alsan and Schultheiss 2002). In contrast, Heartless - the Drosophila fibroblast growth factor receptor-is required not for specification per se, but rather for cardiac precursor cells to assume their right position to receive the specifying cues (Gisselbrecht et al. 1996).

Wingless in Drosophila and the related Wnt proteins in vertebrates comprise the third class of secreted signal for cardiac specification. In this case, however, both induction and suppression have been reported. Wingless is essential for cardiogenesis in flies, as cells exposed just to Dpp become visceral muscle instead (Zaffran and Frasch 2002). Surprisingly, given these results, Wnt signaling blocks cardiogenesis in heart field explants from the chick and in microinjected Xenopus embryos overexpressing Wnt3A or Wnt8 (Fig. 2; Marvin et al. 2001; Schneider and Mercola 2001; Tzahor and Lassar 2001). Likewise, inhibitors of the Wnt signaling cascade can induce cardiogenic differentiation ectopically, in presumptive blood-forming cells and anterior paraxial mesoderm. Furthermore, endogenous Wnt antagonists (Crescent, Dickkopf-1) appear to be critical signals from the organizer or anterior endoderm to disinhibit cardiac specification in the adjacent mesoderm.

Making matters more complex is the recent report that Wnt11 stimulates cardiogenesis in avian explants, a quail mesodermal cell line, Xenopus, and mouse P19 cells (Eisenberg et al. 1997; Eisenberg and Eisenberg 1999; Pandur et al. 2002). At least in the latter two systems, such procardiogenic signals are transduced through the "noncanonical" Wnt pathway, involving protein kinase $\mathrm{C}$ and Jun $\mathrm{N}$-terminal kinase (Pandur et al. 2002). Thus, with regard to cardiogenesis, both positive- and negative-acting Wnts exist.

The primary mode of Wingless/Wnt signaling is through an intracellular cascade that inhibits activity of glycogen synthase kinase-3 (GSK3), which phosphorylates armadillo/ $\beta$-catenin, a transcriptional coactivator that associates with high-mobility group (HMG)-box transcription factors of the T-cell factor (TCF) family, converting them from repressors to activators (for review, see Harwood 2001). Phosphorylation of $\beta$-catenin by GSK3 targets it for degradation by the ubiquitin pathway, thereby suppressing TCF-dependent transcription. Consistent with a suppressive effect of Wnts on cardiogenesis, expression in anterior mesodermal cells of activated GSK3, which inhibits signaling from $\beta$-catenin to TCFs, can promote cardiogenesis (Schneider and Mercola 2001). The target genes of TCFs that suppress cardiogenesis remain to be identified. Remarkably, conditional deletion of $\beta$-catenin in definitive endoderm of the mouse leads to the formation of ectopic hearts (Lickert et al. 2002). Although this experiment was construed as consistent with Wnts' inhibitory effects on heart formation in other vertebrates, ectopic expression of BMP2 resulting from loss of $\beta$-catenin is a likely instigating factor.

A Wnt- and $\beta$-catenin-dependent pathway for mammalian cardiac myogenesis, resembling the primordial Wnt pathway in flies, is operative and essential for cardiac differentiation in pluripotent mouse P19CL6 cells (Nakamura et al. 2003). In this clonal line, expression of 
Figure 2. Signaling pathways leading to cardiac specification. Signaling pathways from the membrane to the nucleus involved in mammalian cardiogenesis are shown. Wnts act through seven-transmembrane frizzled receptors. Wnt-3a and Wnt 8 act through a canonical signaling pathway involving GSK3 and $\beta$-catenin to target TCF, which represses cardiogenesis. The anticardiogenic activity of Wnt-3a/8 can be suppressed by Crescent, Dickkopf and soluble frizzleds in the extracellular milieu, and by $\mathrm{Li}^{2+}$, which inhibits GSK3 activity. Wnt-11, which acts through $\mathrm{PKC} / \mathrm{JNK}$, possesses procardiogenic activity; the nuclear target in this pathway is unknown. BMPs act through two receptors, RI and RII, and activate bifurcating signaling cascades mediated by Smad and the kinases TAK and p38, which target ATF transcription factors. The soluble BMP antagonist Noggin suppresses the procardiogenic function of BMP.

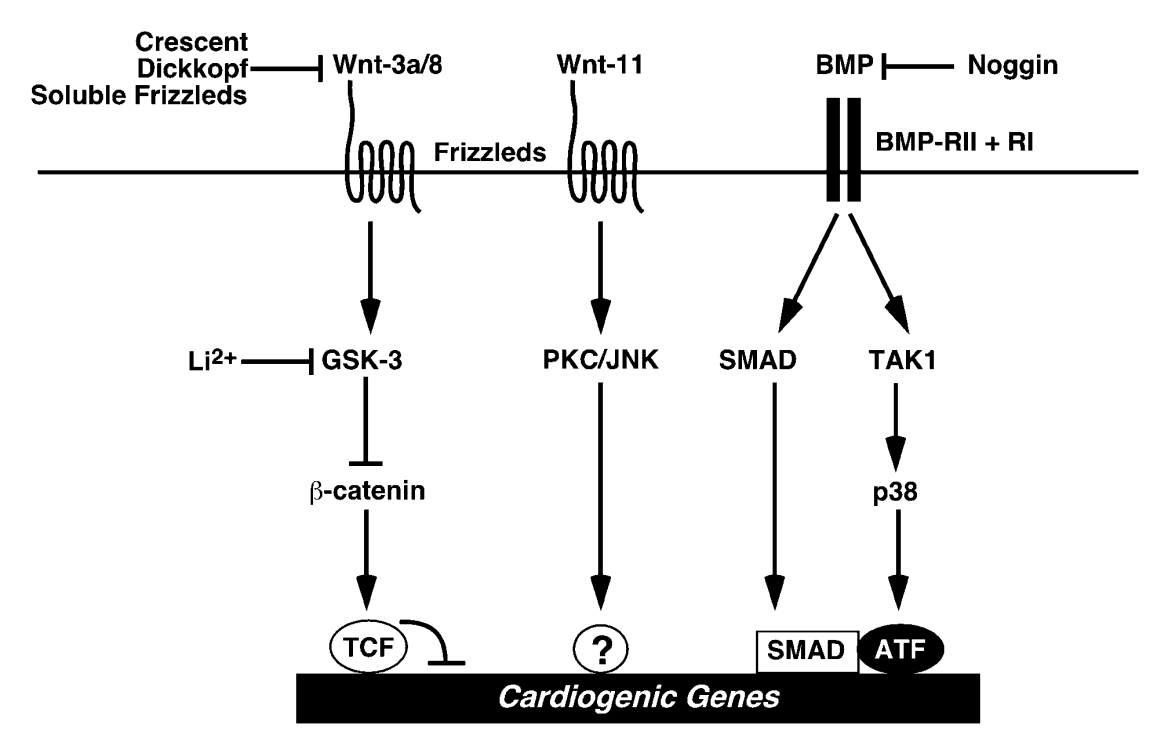

BMPs was a relatively late response to the differentiating signal dimethylsulfoxide, Wnt3A and 8A were early transient responses, exogenous Wnt3A and 8A promoted cardiac differentiation, and Wnt or $\beta$-catenin inhibitors blocked differentiation. As a potential point of reconciliation with the endoderm-restricted loss of $\beta$-catenin, Wnt inhibitors blocked the induction of endogenous BMP2 and BMP4 (Nakamura et al. 2003). Hence, Wnts govern BMP expression in both settings. However, in the absence of molecular markers for the molecularly unspecified cardiac progenitor, a caveat in this clonal system [and also in mouse embryonic stem (ES) cells or pluripotent cells of other kinds] is that the Wnt $\beta$ catenin cascade could act extrinsic to the future cardiomyocyte by induction, expansion, or augmentation of BMP-producing endoderm-like cells. A similar cautionary note pertains to experiments in embryos or explants.

In summary, recent advances reinforce the central, indispensable role of BMP signaling in cardiac myogenesis and later cardiac morphogenesis. The role of Wnts in vertebrate heart formation, first thought to be merely suppressive, is more complex than envisioned, encompassing induction of cardiogenic differentiation by alternative Wnt isoforms, alternative Wnt mediators, and even a Wnt- $\beta$-catenin-TCF cassette like the archetypal pathway in flies.

Other extracellular cues may also contribute to cardiac specification, including TGF $\beta$ family members beyond just BMPs. Nodal, for instance, has been implicated in heart formation, in large part from the reduction in myocardium in zebrafish mutants (one-eyed pinhead) lacking its coreceptor, a member of the epidermal growth factor (EGF) family (Griffin and Kimelman 2002). An analogous role is reported, in mice, for Cripto, the founding member of this family (Xu et al. 1998, 1999). However, a complication akin to that detailed earlier for the exact role played by Wnts is that mesoderm and en- doderm are defective, much more generally, in both mice and zebrafish lacking these signaling molecules (Ding et al. 1998; Gritsman et al. 1999).

\section{Specification of cardiac cell fate by multiprotein complexes of cardiogenic transcription factors}

Anterior mesodermal cells receiving the appropriate set of signaling inputs switch on a set of cardiac-restricted transcription factors that interact in combinatorial ways to control downstream genes in the cardiac pathway. The homeodomain transcription factor Nkx2.5 (Lints et al. 1993) and the T-box protein Tbx5 (Bruneau et al. 1999; Horb and Thomsen 1999) are among the earliest markers of the cardiac lineage. Forced expression of Nkx2.5 in Xenopus and zebrafish embryos can expand the heart-forming region /Chen and Fishman 1996; Cleaver et al. 1996), whereas expression of dominant negative-Nkx2.5 (Tonissen et al. 1994; Evans et al. 1995) and Tbx 5 mutant proteins eliminates the heart (Horb and Thomsen 1999). Nkx2.5 and Tbx-5 associate with members of the GATA family of zinc-finger transcription factors and with serum response factor (SRF), a MADS (MCM1, Agamous, Deficiens, serum response factor) box transcription factor, to activate cardiac structural genes (Chen and Schwartz 1996; Sepulveda et al. 1998, 2002; Belaguli et al. 2000; Bruneau et al. 2001). The Nkx2.5 and GATA genes are also regulated by Nkx2.5 and GATA factors, fulfilling positive feedback loops that amplify and maintain their expression following entry of cells into the cardiac lineage (Schwartz and Olson 1999; Molkentin et al. 2000). Ectopic expression of GATA5 can also induce cardiac genes and beating foci of myocardial tissue in zebrafish embryos, whereas heart formation is compromised in fish lacking GATA5 (Reiter et al. 1999). However, none of these factors alone or in combinations can induce endogenous cardiac gene expression in cul- 
tured cells, suggesting that other factors and/or signals that coexist in vivo are required for their ability to confer cardiac induction. Alternatively, the cardiac program might be responsive only to a very precise stoichiometry of these factors that is difficult to achieve in ectopic expression assays.

Despite their apparent importance in early cardiac development, deletion of the genes encoding Nkx2.5, Tbx5, and GATA factors in knockout mice does not prevent specification or differentiation of cardiomyocytes, but instead results in later abnormalities in cardiac morphogenesis (Lyons et al. 1995; Kuo et al. 1997; Molkentin et al. 1997; Tanaka et al. 1999; Bruneau et al. 2001). The lack of early cardiac phenotypes in these mutants is likely to reflect redundant mechanisms for regulation of the initial steps in the cardiac pathway, including structural homologs in each of these three families as well as functional redundancy by unrelated proteins.

A critical role for SRF in cardiogenesis has been inferred from transfection assays demonstrating the essential role of SRF binding sites for cardiac gene transcription (Chen and Schwartz 1996; Reecy et al. 1999) and from the especially high levels of SRF in the developing heart (Croissant et al. 1996). However, the function of SRF in heart development in vivo has been clouded by the early lethality of SRF null mice prior to the onset of cardiogenesis (Arsenian et al. 1998). SRF recruits a powerful transcriptional coactivator, called myocardin, to activate transcription of cardiac genes (Wang et al. 2001). A myocardin dominant-negative mutant protein can prevent heart formation in Xenopus embryos (Wang et al. 2001), and forced expression of myocardin can activate ectopic cardiac gene expression even in spinal cord neurons of transgenic frogs (E. Small, E. Olson, and P. Krieg, unpubl.). Myocardin also acts as a master regulator of smooth muscle genes, suggesting commonalities in the cardiac and smooth muscle gene programs (J. Chen et al. 2002; Du et al. 2003; Wang et al. 2003; Yoshida et al. 2003). It is interesting to note, in this regard, that the early heart tube resembles a primitive vessel and transiently expresses smooth muscle genes. Cysteine-rich LIM-only proteins serve as especially potent coactivators of SRF and GATA factors in the context of smooth muscle differentiation, even activating the endogenous smooth muscle gene program (Chang et al. 2003). Given the right combination of SRF, bridging factors, and tissue-specific cofactors, a related complex might be expected to be instrumental in cardiogenesis as well.

\section{Control of cardiomyocyte differentiation}

Unlike skeletal muscle cells, in which proliferation and differentiation are mutually exclusive, embryonic cardiac myocytes differentiate and assemble functional sarcomeres even while they proliferate, although the extent of sarcomere organization is far less than after birth. Members of the myocyte enhancer factor-2 (MEF2) family of transcription factors play a key role in the control of cardiomyocyte differentiation by switching on cardiac muscle structural genes whose products participate in myofibrillogenesis and muscle metabolism (for review, see McKinsey et al. 2002). The four vertebrate MEF2 genes (MEF2A, $M E F 2 B, M E F 2 C$, and $M E F 2 D)$ are expressed in overlapping patterns throughout the developing heart. Mice lacking MEF2C die at the onset of cardiac looping and show severe ventricular hypoplasia with reduced expression of a subset of cardiac structural genes (Lin et al. 1997). Likewise, the single MEF2 gene in Drosophila is required for differentiation of cardiac muscle cells and dispensable for initial steps in cardiac lineage commitment and heart tube patterning (Bour et al. 1995; Lilly et al. 1995; Ranganayakulu et al. 1995). A very different phenotype results from deletion of MEF2A - a deficiency of cardiac mitochondria and susceptibility to sudden death, which is attributed to the very different developmental regulation of MEF2A, the predominant MEF2 protein in postnatal hearts (Naya et al. 2002). It is unknown whether differences in MEF2 target-site specificity or MEF2-binding proteins also contribute to functional differences among the four family members. Given that MEF2 in adult hearts provides a nexus for repression of certain "fetal" cardiac genes in the absence of hypertrophic signals (a point discussed at length following), it is intriguing to speculate how MEF2-dependent transcription becomes permissible during embryogenesis; if analogy to skeletal muscle holds true, equivalent processes might be involved at both stages.

\section{Morphogenesis and growth of the embryonic heart}

Soon after their specification, cardiac precursor cells from the cardiac crescent converge along the ventral midline of the embryo to form the linear heart tube, which undergoes looping, chamber growth and specification, and septation to ultimately generate the structure of the multichambered heart (Fig. 1; for reviews, see Fishman and Chien 1997; Srivastava and Olson 2000; Harvey 2002). Looping morphogenesis, the earliest of left-right asymmetries in the developing organism, is regulated by a complex network of growth factors, but even may involve patterning, in Xenopus, at the four-cell stage (Levin et al. 2002). Growth of the primary heart tube has been shown to occur through ballooning of the outer curvature of the ventricular segments /Christoffels et al. 2000). In addition to the many genes discussed following, intracardiac flow forces play a key epigenetic role in fashioning the early heart (Hove et al. 2003). Because our focus here is specifically on those trophic and transcriptional circuits with most immediate relevance for mechanisms or countermeasures in adult disease, we direct readers elsewhere for coverage of other topics (Rosenthal and Xavier-Neto 2000; Srivastava 2001; Tabin and Vogan 2003).

The phenotypes of mouse and zebrafish mutants have led to the notion that the heart develops in a segmental fashion, with the growth of each chamber dependent on distinct combinations of transcription factors (Fishman and Olson 1997). This is consistent with the abnormalities associated with hypoplastic heart syndromes in humans, in which one ventricular chamber or the other is 
underdeveloped or absent and the other is largely normal. During mouse embryogenesis, the basic helix-loophelix transcription factors, HAND1 and HAND2, are expressed in highly restricted patterns in the developing left and right ventricular chambers, respectively (Srivastava et al. 1995). In mice lacking HAND2, the right ventricular chamber fails to grow; instead, presumptive right ventricular myocytes undergo apoptosis resulting in a lethal hypoplastic ventricular phenotype (Srivastava et al. 1997; Thomas et al. 1998). This cardiac phenotype is reminiscent of that of embryos lacking the SET (position effect variegation suppressor $\underline{\mathrm{Su}}(\mathrm{Var}) 3-9$, Enhancer of Zeste, Trithorax)-domain protein BOP, a cardiac-restricted transcriptional repressor that is regulated by HAND2 (Gottleib et al. 2002). Placental abnormalities in HAND1 mutant mice have complicated the analysis of the role of this gene in cardiac development (Firulli et al. 1998; Riley et al. 1998), although HAND1 null ES cells fail to contribute to the left ventricle in chimeric mice (Riley et al. 2000). Cardiac-specific deletion of HAND1 results in severe cardiac malformations as well (D. McFadden, A. Barbosa, and E.N. Olson, unpubl.). The "floxed" allele also provides an opportunity to test the role of HAND1 in adult myocardium, especially as HAND1 is down-regulated during cardiomyopathy (Natarajan et al. 2001; Thattaliyath et al. 2002). Further evidence for an obligate role of HAND genes in ventricular growth comes from the analysis of mice lacking Nkx2.5, which fail to express HAND1 in the future left ventricular region and die at midgestation from a block in cardiac morphogenesis (Biben and Harvey 1997). In mice lacking HAND2 and Nkx2.5, neither HAND gene is expressed in the heart, resulting in a near complete absence of ventricular myocardium (Yamagishi et al. 2001). However, this phenotype is much more severe than that of mice with a cardiac-specific deletion of HAND1 combined with a HAND2 deletion (D. McFadden, A. Barbosa, and E. Olson, unpubl.), suggesting that $\mathrm{Nkx} 2.5$ has essential downstream target genes in addition to HAND1.

$\mathrm{Tbx} 5$ is also required for proper growth of the myocardium. Mutations in Tbx5 are responsible for Holt-Oram syndrome, which is characterized by a spectrum of cardiac defects including hypoplastic left ventricle, atrialseptal defects, and ventricular-septal defects (Bruneau et al. 2001). As in the majority of other cardiac mutants, the target genes of this transcription factor responsible for these structural abnormalities remain to be defined.

There is an intriguing linkage between abnormalities in growth and patterning of the heart and limbs such that human syndromes, such as Holt-Oram syndrome, are associated with malformations in both structures. In HoltOram syndrome, missense mutations in different domains of Tbx5 preferentially cause heart or hand abnormalities, which supports the notion that Tbx5 may engage different cofactors to govern the growth and patterning of these tissues (Basson et al. 1999). HAND2 has also been implicated in limb patterning. In mice and zebrafish lacking HAND2, limb bud outgrowth is impaired, reflecting the failure of the morphogen sonic hedgehog to be expressed in the zone of polarizing activ- ity (Charite et al. 2000; Yelon et al. 2000). Conversely, misexpression of HAND2 in the anterior compartment of the limb bud is sufficient to generate an ectopic zone of polarizing activity with resulting polydactyly and posterior digit duplication. As mentioned subsequently, other lessons from the limb bud to the heart may include a better understanding of mechanisms underlying successful regenerative growth.

\section{Extracellular signals for ventricular growth}

The identification of essential mitogens for cardiomyocyte growth during embryogenesis may have pivotal implications of two kinds after birth: for pathways that confer just cell enlargement once irreversible cell cycle exit has transpired, and for the proliferation of potential regenerative cells. Prior to embryonic day 9.5 (E9.5) in the mouse, the looped heart tube is a thin-walled structure with the atrial and ventricular chambers molecularly specified, but indistinct (Fig. 1). Growth of the heart from this stage onward involves proliferation of myocytes along the walls of the heart tube and within the developing interventricular septum. The most highly proliferative cardiomyocytes are located along the outer surface of the heart, a region called the compact zone (Fig. 1). Fate mapping experiments have shown that individual cardiomyocyte precursors give rise to coneshaped growth units within the ventricular wall (Mikawa et al. 1992). As the wall thickens, cardiomyocytes along the inner wall become organized into fingerlike projections, called trabeculae, which are thought to enhance oxygen and nutrient exchange and force generation.

The epicardium, the thin layer of cells surrounding the heart, serves as a source of mitogenic signals that are necessary and sufficient to stimulate proliferation of cardiomyocytes within the compact zone. Retinoic acid (RA) produced by the epicardium is one critical regulator of cardiac growth. Knockout mice lacking the RA receptor $\mathrm{RXR} \alpha$ die during embryogenesis from a failure in proliferative expansion of ventricular cardiomyocytes resulting in a thin-walled ventricle (Sucov et al. 1994; Kastner et al. 1997). This cardiac defect is recapitulated by epicardium-specific deletion of $\operatorname{RXR} \alpha$, but not by cardiomyocyte-specific deletion of the gene, confirming that the effects of RA on cardiac growth are nonmyocyte autonomous, as concluded also from chimeric embryos (Chen et al. 1998; Tran and Sucov 1998). Consistent with the role of the epicardium as a source of RA for myocardial growth, the epicardium expresses high levels of retinaldehyde-oxidizing dehydrogenase (RALDH2), a key RA synthetic enzyme, and an RA-sensitive lacZ reporter gene is highly expressed in the epicardium and developing heart (Moss et al. 1998). In addition to these effects emphasizing the contribution of RA to ventricular growth, other functions of this pathway are noteworthy, such as the requirement for RA in posterior chamber specification, shown by the knockout of the RALDH2 gene (Niederreither et al. 2001) and by administration of ectopic RA (Xavier-Nato et al. 1999). 
Mice lacking erythropoietin (epo) or the epo receptor show cardiac growth defects ascribed to another nonmyocyte autonomous mechanism (Wu et al. 1999) involving the ability of RA and epo to promote cardiomyocyte proliferation in the presence of epicardium, but not in its absence (T.H. Chen et al. 2002; Stuckmann et al. 2003). The identity of the epicardium-dependent cardiac mitogen remains to be determined.

Growth signals from the endocardium, the specialized endothelial lining of the heart, are critical as well. The neuregulin family of peptide growth factors and their tyrosine kinase receptors (ErbBs), first implicated in oncogenic signaling in breast cancer cells, have also been shown to promote growth of embryonic cardiomyocytes in vivo (Zhao et al. 1998) and play multiple roles in the intact heart (for review, see Garratt et al. 2003). Knockout mice lacking ErbB2 (a coreceptor for other Erbs), Erb4, or neuregulin-1 die at midgestation from cardiac growth defects characterized by the absence of trabeculae (Gassmann et al. 1995; Lee et al. 1995). This abnormality can be ascribed to the lack of paracrine signaling between the endocardium and myocardium. Mice lacking the ShcA adaptor protein, which signals downstream of ErbB receptors, show a similar cardiac growth phenotype (Lai and Pawson 2000). Cardiac-specific deletion of ErbB2 results in dilated cardiomyopathy with ventricular wall thinning in adult animals (Crone et al. 2002) reminiscent of the cardiac phenotype observed in some breast cancer patients receiving anti-ErbB2 antibody therapy. The precise etiology of this form of cardiomyopathy remains to be determined, but may involve the perturbation of a cardiac cell survival pathway. Neuregulins have also gained interest as an inductive signal for the heart's specialized conduction system (Rentschler et al. 2002).

\section{Nuclear regulators of cardiac growth}

Several genes with key roles in the control of cardiac growth during embryogenesis have recently been discovered. One such gene encodes a homeodomain called homeodomain-only protein (HOP) that appears to play a dual role in the control of cardiac growth during embryogenesis and early prenatal development (F. Chen et al. 2002; Shin et al. 2002). During mid-embryogenesis, HOP is expressed predominantly in the trabecular region of the myocardium (where cardiomyocyte proliferation is diminished). HOP null mice segregate into two classes that exhibit either an excess or deficiency of cardiac myocytes. Mutants with myocyte deficiency die during early embryogenesis as a result of cardiac insufficiency. Paradoxically, embryos that can survive this critical period show an excess of cardiac myocytes after birth. These antithetical phenotypes suggest a role for HOP in regulating the balance between proliferation and differentiation, which may depend on the spectrum of available partners for HOP as well as the signals received by the cardiac myocyte at a given time and place in the developing heart. Alternatively, the increased number of cardiomyocytes in survivors may reflect a successful secondary adaptation.

Genetic screens in zebrafish have also led to the identification of novel genes that affect cardiac growth. Among these is Reptin, a component of a DNA-stimulated ATPase complex that is associated with Pontin, thought to be a DNA helicase that antagonizes Reptin activity (Rottbauer et al. 2002). Reptin and Pontin bind the $\beta$-catenin/TCF complex, a critical mediator of Wnt signaling discussed earlier. Consistent with their proposed antagonistic roles, Reptin is a transcriptional corepressor for $\beta$-catenin/TCF-dependent repression, whereas Pontin acts in an opposing manner. In zebrafish embryos bearing an activating mutation of Reptin, cardiomyocytes exhibit a cell-autonomous excess in proliferation. Reducing the expression of Pontin phenocopies the hyperplasic effect of Reptin, supporting the notion that Reptin and Pontin act in antagonistic manners to drive and suppress cardiomyocyte proliferation, respectively. The specific targets of Reptin and Pontin and the $\beta$-catenin pathway in this process remain to be determined.

\section{Hypertrophy}

Growth of the heart during embryogenesis occurs primarily through proliferation of cardiac myocytes. However, soon after birth, cardiac myocytes withdraw irreversibly from the cell cycle and subsequent growth of the heart occurs predominantly through hypertrophy rather than myocyte hyperplasia. In broad terms, there are two forms of cardiac hypertrophy, physiological, as occurs in response to exercise, and pathological, as occurs in response to abnormal stress. Stress signals that induce hypertrophy include hypertension, pressure overload, endocrine disorders, myocardial infarction, and contractile dysfunction from inherited mutations in sarcomeric or cytoskeletal proteins. Pathological hypertrophy frequently progresses to dilated cardiomyopathy (Fig. 3), which may be due, at least in part, to activation of apoptotic pathways (for review, see Kang and Izumo 2003). Certain pathological signals also cause cardiac dilatation without an intermediate hypertrophic stage. There is general agreement that cardiac hypertrophy is triggered by abnormalities in calcium homeostasis within the cardiomyocyte (for review, see Frey et al. 2000a). However, the mechanism whereby calcium, which fluctuates in concentration by orders of magnitude during each cycle of contraction and relaxation, can activate hypertrophic signaling remains vague.

Hypertrophic growth involves control at multiple molecular levels: transcription initiation, transcript elongation, and protein translation (Fig. 4). An intricate web of interconnected signaling modules has been implicated in hypertrophy of postnatal cardiomyocytes (for reviews, see Hunter and Chien 1999; Molkentin and Dorn 2001). These signaling pathways culminate in the nucleus with the posttranslational activation of a set of transcription factors, all of which have earlier roles in heart development (Fig. 4). When activated in the adult myocardium, 


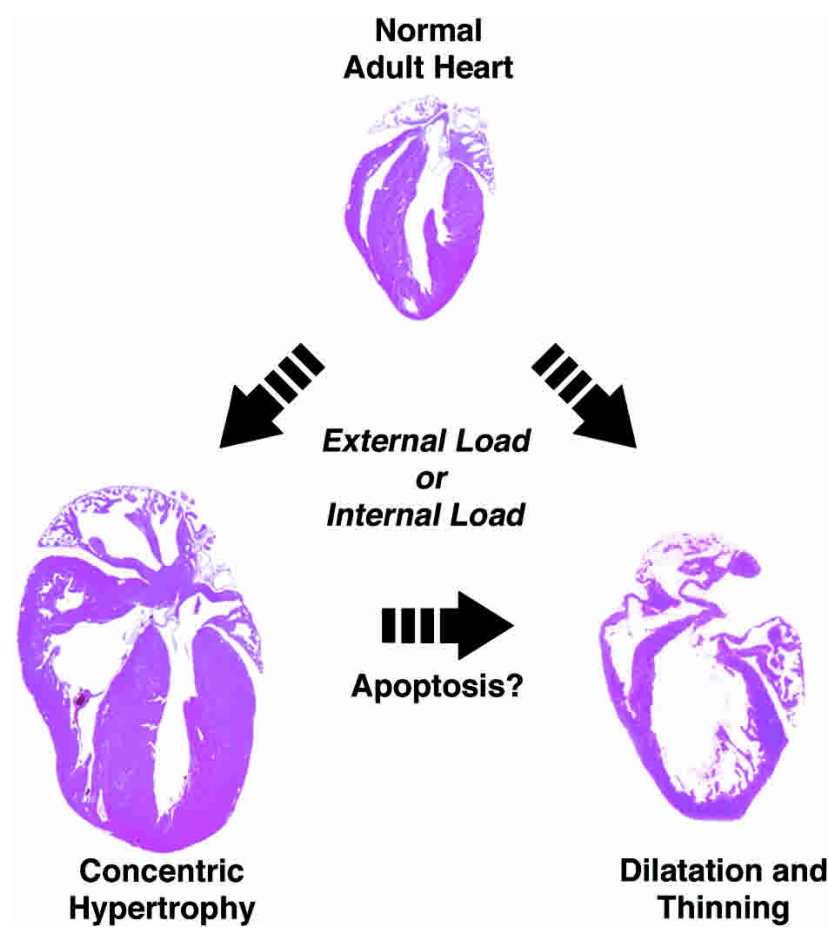

Figure 3. Growth of the adult heart by hypertrophy and dilation. The adult heart can undergo concentric hypertrophic growth that progresses to dilated cardiomyopathy or it can undergo dilatation directly through the actions of pathological signaling pathways that impose external or internal load.

these factors reawaken a "fetal" cardiac gene program. Although elements of this program might be salutary adaptations to stress initially, it has become increasingly clear, if not arguable, that the aberrant expression of fetal proteins involved in contractility, calcium handling, and myocardial energetics leads to maladaptive changes in cardiac function (Miyata et al. 2000). Several counterregulatory mechanisms have also been identified in hypertrophic signaling circuits that provide opportunities for pharmacological and genetic interference with pathological signaling from the cytoplasm to the nucleus.

\section{The MAP kinase module}

Mitogen-activated protein (MAP) kinase signaling through each of the three terminal MAPK families (ERK, JNK, and p38) plays a key role in hypertrophy, with differing effects, respectively, on growth per se versus the fetal gene program and cardiomyocyte survival (for review, see Sugden and Clerk 1998). For instance, MAPKKK7 (also known as TGF- $\beta$ activated kinase) is activated as a late response to mechanical load and is sufficient, at pathophysiological levels of function, to drive an apoptotic cardiomyopathy in mice (Zhang et al. 2000). Numerous upstream initiating triggers for this pathway have been identified, but relatively little is known of the transcriptional targets that ultimately integrate such signals. Notably, MEF2 factors are phos- phorylated by MAP kinases, which augments their transcriptional activity (McKinsey et al. 2002). GATA factors and ATF transcription factors, both cofactors for SRF, also are stimulated by MAP kinase phosphorylation (Zhang et al. 2000; Liang et al. 2001; Monzen et al. 2001).

\section{The calcineurin module}

The calcium-dependent phosphatase calcineurin is an especially powerful activator of cardiac growth, both sufficient and in some cases necessary for hypertrophy in response to diverse stimuli, including the signals discussed earlier (Molkentin et al. 1998). Calcineurin, which is localized to the cytoplasm and the Z-line of the sarcomere (Frey et al. 2000b), is activated by a specific waveform of calcium. Pharmacological inhibition of calcineurin with cyclosporin A or FK-506, or genetic inhibition in calcineurin knockout mice or transgenic mice expressing dominant negative forms of the protein, abrogates cardiac growth (for review, see Leinwand 2001).

Members of the nuclear factor of activated $\mathrm{T}$ cells (NFATs) are among the key substrates of calcineurin (Crabtree and Olson 2002). Dephosphorylation of NFAT proteins by calcineurin results in their translocation to the nucleus where they interact with GATA and MEF2 transcription factors, providing a link between calcium signaling and fetal cardiac gene expression (Molkentin et al. 1998). It is interesting to note that NFAT proteins have also been implicated in growth of skeletal muscle in response to the cytokine interleukin 4 (IL-4; Horsley et al. 2003). Whether similar cytokine signaling pathways govern cardiac growth remains to be determined.

NFATs are rephosphorylated by GSK3, resulting in their export from the nucleus and termination of calcium-dependent transcription. Thus, GSK3 can impose a powerful restraint on prohypertrophic signaling by sustaining the phosphorylation of NFAT proteins (and probably other substrates), thereby antagonizing the actions of calcineurin. The suppression of GSK3 activity by the kinase Akt/protein kinase B provides a crossover point between the calcineurin and insulin-like growth factor (IGF)-phosphoinositide 3-kinase (PI3K) signaling pathways (Fig. 4). GSK3 has also been shown to promote nuclear export of GATA4, which would be predicted to antagonize hypertrophic signaling (Morisco et al. 2001). Consistent with this conclusion, transgenic mice that express a constitutively active form of GSK3 are resistant to intrinsic and extrinsic hypertrophic signals (Antos et al. 2002). Remarkably, despite the lack of "adaptive" growth, these mice sustain normal cardiac function in the face of cardiac stress.

Calcineurin signaling in the heart is also suppressed by a family of calcineurin regulatory proteins known as modulatory calcineurin interacting proteins (MCIPs), which interact with the calcineurin catalytic subunit to inhibit activity (Rothermel et al. 2001). MCIP1 is upregulated by calcineurin signaling through a series of NFAT sites in its promoter (Yang et al. 2000), creating a negative feedback loop to dampen calcineurin signaling. Accordingly, transgenic overexpression of MCIP in the 


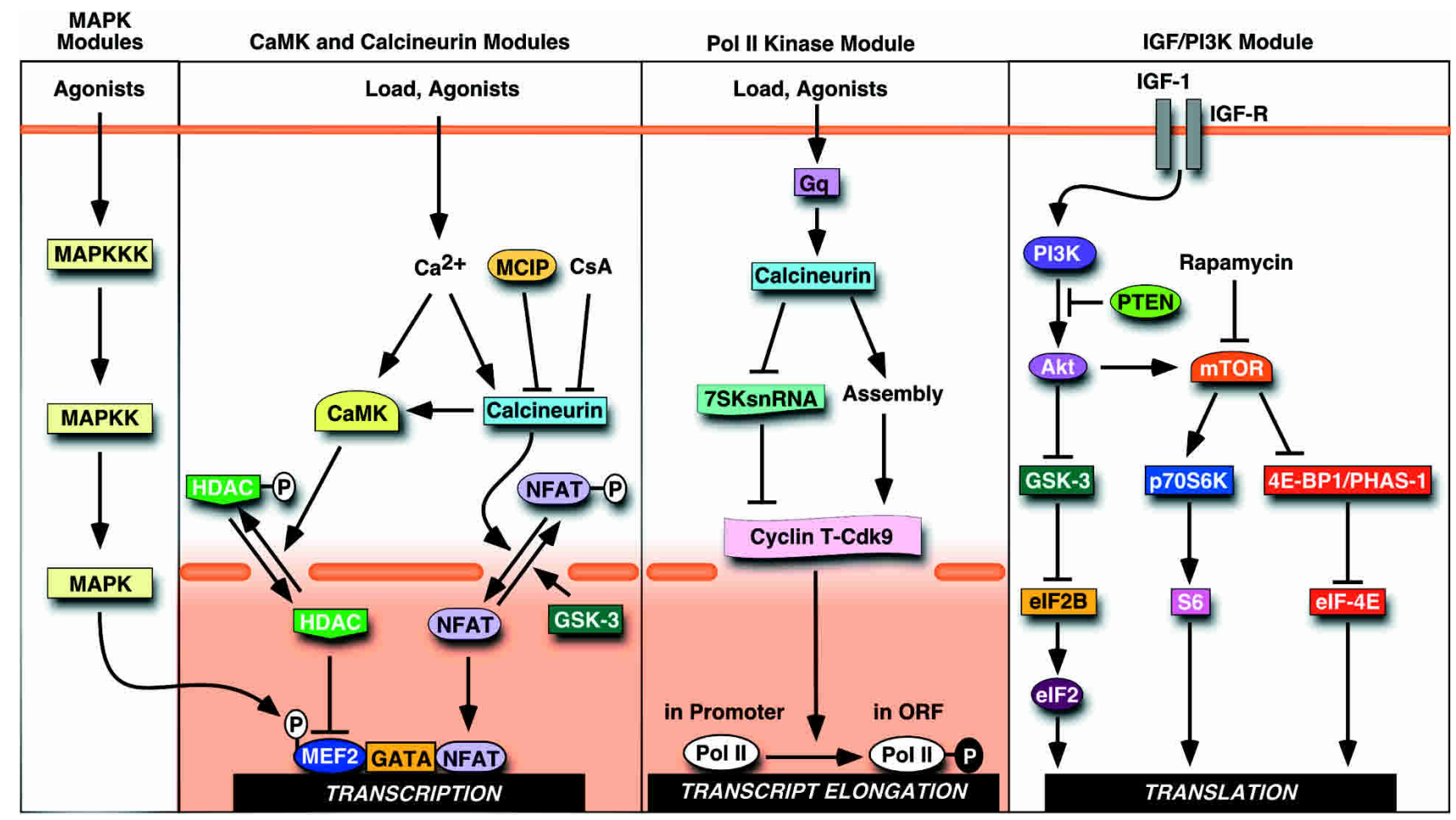

Figure 4. Hypertrophic signals leading to fetal gene activation, myocyte enlargement, or both. Four signaling modules that promote hypertrophy with activation of the fetal gene program in response to diverse agonists and load are shown. One key target of the MAPK module is MEF2, which cooperates with GATA and NFAT transcription factors to drive hypertrophy and fetal gene expression in the adult heart. The CaMK and calcineurin module uses calcineurin to dephosphorylate NFAT, which enters the nucleus to engage GATA and MEF2. CaMK signaling dephosphorylates class II HDACs, resulting in their dissociation from MEF2 and consequent potentiation of MEF2 activity. Calcineurin signaling also activates the HDAC kinase through an unknown mechanism. Calcineurin enhances transcript initiation via a cyclin T-Cdk9 complex that phosphorylates RNA polymerase II. IGF stimulates translation by the Akt kinase and its downstream effectors controlled by GSK3 and mTOR.

heart confers resistance to pressure overload, chronic adrenergic stimulation, and exercise (Rothermel et al. 2001).

These studies would predict that MCIP knockout mice might be supersensitive to hypertrophic signals and indeed they rapidly develop a lethal cardiomyopathy in response to constitutive calcineurin activation (Vega et al. 2003). However, these mice show a reduced responsiveness to pressure overload and adrenergic stimulation. These findings have led to a model in which MCIPs are both permissive for calcineurin activation, possibly by performing a chaperone function, and repressive to excessive levels of calcineurin activity. The single MCIP gene in yeast, rgs, plays a similar dual role in governing calcineurin functions (Bonilla et al. 2002).

\section{The MEF2-HDAC module}

The MEF2 transcription factor also serves as a target for hypertrophic signaling (Lu et al. 2000; Nadruz et al. 2003). In the normal adult myocardium, MEF2 exhibits only basal activity, which is likely to be required for maintenance of contractile protein gene expression and energy metabolism (Passier et al. 2000; Naya et al. 2002). Stress signaling stimulates the transcriptional activity of MEF2 by causing the nuclear export of class II histone deacetylases (HDACs), which associate with MEF2 and suppress its activity (Fig. 4; McKinsey et al. 2000). Nuclear export of class II HDACs is mediated by a stressresponsive protein kinase with the same substrate specificity of CaM kinase, a potent activator of MEF2 and hypertrophy (Zhang et al. 2002). These kinases phosphorylate two conserved sites in HDACs that create docking sites for the 14-3-3 family of chaperone proteins. Binding of 14-3-3 to these phosphoacceptors results in dissociation from MEF2 and nuclear export with consequent derepression of MEF2 activity (for review, see McKinsey et al. 2002).

Consistent with the notion that class II HDACs act as suppressors of cardiac growth and fetal gene activation, mice lacking HDAC9 are supersensitive to stress signals (Zhang et al. 2002). Conversely, expression of signal-resistant HDAC mutants in primary cardiomyocytes is sufficient to suppress fetal gene activation in response to hypertrophic signaling. Paradoxically, HDAC inhibitors currently being tested in clinical trials as anticancer agents block cardiomyocyte hypertrophy and fetal gene expression (Antos et al. 2003). The basis for this anticar- 
diac growth effect remains to be defined. However, it is interesting to speculate that this activity reflects a procardiac growth function of certain HDACs that are dominant over the growth inhibitory function of HDAC9 and other class II HDACs.

\section{The cyclin T-cdk9 pathway}

An additional mechanism to control protein accumulation in hypertrophic cardiomyocytes involves the global increase in RNA transcription via hyperphosphorylation of the C-terminal domain (CTD) of RNA polymerase II (Fig. 4; Sano et al. 2002; Sano and Schneider 2003). Whereas unphosphorylated polII is the form recruited to promoters for transcript initiation, phosphorylation of polII is implicated in productive transcript elongation, that is, the ability of polII to escape the promoter-proximal region and enter the open reading frame (Orphanides and Reinberg 2002). Diverse hypertrophic signals including the agonist endothelin-1, mechanical load, the G protein $\mathrm{G} \alpha \mathrm{q}$, and calcineurin have been shown to stimulate activity of cyclin-dependent protein kinase 9 (cdk9), which phosphorylates the polII CTD, by inducing the dissociation of its endogenous inhibitor, a small nuclear RNA inhibitor (7SK; Sano et al. 2002). Blockade of 7SK expression with antisense oligonucleotides resulted in spontaneous hypertrophy, as did transgenic overexpression of the cdk9 activator cyclin T. Chronic hypertrophic signals activate Cdk9 through an additional mechanism, as well, involving increased assembly of the cyclin T-Cdk9 complex (M. Sano and M. Schneider, unpubl.).

\section{The IGF-PI3K module}

Growth of the heart after birth has been shown to involve the IGF signaling pathway, which signals through PI3K to the Akt/protein kinase B (Shioi et al. 2002). This same pathway controls cell, organ, and body size in Drosophila (Cantley 2002). Manipulation of this pathway by overexpression of IGF1 induces cardiac hypertrophy (Delaughter et al. 1999), although cardiomyocyte hyperplasia has also been reported in some studies (Reiss et al. 1996). A key downstream target of Akt in this pathway is GSK3 (Fig. 4). Phosphorylation by Akt inactivates GSK3 and results in stimulation of protein synthesis. In addition, Akt has been proposed to activate the mammalian target of rapamycin (mTOR), which stimulates protein synthesis by phosphorylating two key effectors, p70 S6 kinase and the elongation factor 4E (eIF4E) inhibitor PHAS-1/4E-BP1 (for reviews, see Schmelzle and Hall 2000; Gingras et al. 2001). Consistent with the central role of this pathway in cardiac growth, hypertrophy in response to pressure overload and various agonists can be attenuated by rapamycin, a lipophilic macrolide that inhibits mTOR activity (Sadoshima and Izumo 1995; Boluyt et al. 1997; Shioi et al. 2003). The lipid phosphatase PTEN also suppresses this pathway by antagonizing the action of PI3K. Accordingly, cardiac-specific deletion of PTEN in mice results in cardiac hypertrophy /Crackower et al. 2002). This pathway has also been implicated in skeletal muscle hypertrophy, suggesting common mechanisms for growth of striated muscles postnatally (Bodine et al. 2001).

\section{Regeneration}

Although hypertrophy can increase cardiac mass in response to stress, it is inadequate to restore cardiac function following myocyte loss, as occurs following myocardial infarction and ischemia-reperfusion injury. In contrast to mammalian skeletal muscle, which can regenerate following injury, the mammalian heart has limited restorative potential. Classically, regeneration of skeletal muscle is achieved through activation of a population of quiescent myogenic precursors known as "satellite" cells associated with the myofiber basal lamina; a second mechanism for reconstitution of skeletal muscle involves multipotent adult stem cells, discovered only recently (for review, see Seale et al. 2001). Satellite cells are activated in response to injury and are recruited into the preexisting myofiber where they support myofiber repair. The heart has not been thought to contain an equivalent satellite cell population. The inability of injured myocardium to repair itself more fully does not appear to reflect a fundamental property of cardiac tissue because the hearts of newts and zebrafish are able to regenerate following injury. Because fetal cardiac myocytes contain functional sarcomeres and are highly proliferative, the mere existence of a contractile apparatus per se cannot account for the inability of adult cardiac myocytes to undergo cytokinesis. However, the sarcomeres of adult cardiomyocytes are more highly ordered and stable than those of fetal myocytes, as evidenced by the lack of M-lines in fetal myocytes. Similarly, cardiomyocytes in newts and zebrafish are more analogous to those of mammalian embryos with respect to their sarcomere organization.

The mechanisms responsible for the blockade to proliferation in terminally differentiated cardiomyocytes are unknown. However, numerous studies have implicated tumor pocket proteins, such as $\mathrm{Rb}$, and cyclin-dependent kinase inhibitors in this process (for reviews, see MacLellan and Schneider 2000; Pasumarthi and Field 2002). Because knockout mice lacking various components of these cell cycle checkpoints show only modest increases in myocyte cell numbers (Poolman et al. 1999), there are likely to be redundant mechanisms involved in preventing adult myocytes from reentering the cell cycle. This would also explain why cardiac tumors, referred to as myxomas, are extraordinarily rare.

\section{Genetic models with altered capacity for cardiac repair}

Notably, several mouse mutations, spontaneous and engineered, have altered capacity for cardiac cell regeneration and myocardial repair. An especially instructive one affects the activity of telomerase, which is associated 
with the potential for long-term self-renewal in "immortal" adult cells-stem cells, tumor cells, and germ cells (Blackburn 2001; Oh et al. 2001). Telomeres enable cells to avoid the end-replication problem (the inability of DNA polymerase to completely replicate DNA ends), using a specific RNA template [telomerase RNA component (TERC)] and an RNA-dependent DNA polymerase, telomerase reverse transcriptase (TERT). Deletion of the RNA template, TERC, in mice abolishes telomerase activity and causes progressive telomere shortening by 3-5 $\mathrm{kb}$ pairs per generation (Blasco et al. 1997). After three to six generations, this null genotype results in critical telomere dysfunction, evidenced by impaired longevity and defects, especially in highly proliferative organs (Rudolph et al. 1999). Cardiac myocytes from late-generation TERC ${ }^{-/-}$mice showed significant telomere shortening and impaired ventricular pump function, ventricular thinning, and apoptosis (Leri et al. 2003).

Conversely, in urodele amphibians such as the newt, cardiac repair-like limb and lens regeneration-is strikingly robust (Oberpriller et al. 1995; Brockes and Kumar 2002). The MRL mouse strain exhibits the remarkably similar feature of cell replacement without scarring, after cardiac injury (Leferovich et al. 2001). First encountered as the perfect and hereditable healing of ear hole punch wounds, the regenerative phenotype in this line appears to involve the collective action of 20 or more genetic loci (McBrearty et al. 1998; Blankenhorn et al. 2003), and is possibly mediated by differences in the activity of matrix metalloproteinases and their inhibitors (Gourevitch et al. 2003). The resemblance of regeneration in this mouse model to epimorphic limb regrowth in newts (Brockes and Kumar 2002) has suggested a mechanism akin to the regeneration blastema: local dedifferentiation of cells underlying the wound, followed by growth and then reversal to the differentiated cell type (Leferovich et al. 2001; Gourevitch et al. 2003). It has been suggested recently that thrombin protease activity after tissue injury might be a pivotal determinant for the onset of regenerative growth (Imokawa and Brockes 2003).

Despite the precedent of heart regeneration in amphibians (Oberpriller et al. 1995), none of the urodeles is tractable genetically. In contrast, recent studies with the zebrafish provide a potential genetic model for dissecting this problem (Poss et al. 2002a). Amputation of the apical ventricle led to rapid clotting at the site, ingrowth of cardiac myofibers over the following weeks, robust myocyte proliferation, and complete replacement of the clot within $60 \mathrm{~d}$, with little or no fibrosis. In a temperaturesensitive mutant of a mitotic checkpoint kinase, mps1, cardiac restitution was incomplete and a reciprocal increase in fibrosis was observed, suggesting that myocyte proliferation determines the extent of scarring (Poss et al. 2002b). Such regeneration, although dramatic, is clearly distinct from the form of regeneration involved in complete reconstitution of a limb, for example, following amputation. It is unknown whether a cell-autonomous effect in cardiomyocytes themselves or in an asyet-unknown progenitor cell is the primary target to ex- plain this phenotype. Alternatively, an extract from regenerating newt limbs drives mouse myotubes to dedifferentiate and reenter the cell cycle (McGann et al. 2001), and deficiencies in cardiac repair could arise from defects in such pathways.

\section{Strategies for cardiac repair}

\section{Cell replacement}

One potential approach for cardiac repair that bypasses cell cycle constraints is to implant additional myocytes into the injured heart. Work with fetal cardiac myocytes established the overall feasibility of this approach, including formation of at least nascent intercalated discs, as required for appropriate connectivity (Soonpaa et al. 1994; Koh et al. 1995; Reinecke et al. 1999). Fetal cardiac myocytes appear to survive better after grafting than do adult ones (Reinecke et al. 1999), prevent the adverse dilatation of ventricular muscle when implanted after ischemic damage, and improve ventricular pump function. However, the actual basis for remediating organlevel function became surprisingly ambiguous, on the discovery that various noncontractile cells were likewise beneficial in enhancing the function of surviving cardiomyocytes (Kocher et al. 2001; Kawamoto et al. 2003), stabilizing or diminishing the myocardial scar, and preventing late myocardial thinning and dilatation. Few side-by-side comparisons, though, have tested directly the premise that contractile cells are better for the heart than noncontractile ones. It has been suggested that ventricular relaxation (diastole) can be improved almost regardless of cell type, whereas ventricular contraction (systole) more specifically requires contractile cells (Sakai et al. 1999; Hutcheson et al. 2000); notably, though, systolic function was improved by marrow-derived angioblasts (Kocher et al. 2001).

Conceivably, skeletal myocytes might substitute for cardiac ones (Taylor et al. 1998), and clinical trials with human skeletal myoblasts have been initiated (Hagege et al. 2003) despite the cells' inherent differences from ventricular myocytes in ion transport, connectivity, and contractile proteins, and despite lack of evidence for their transdifferentiation into cardiac muscle following engraftment (Reinecke et al. 2002). Indeed, as might be anticipated, cardiac arrhythmias have already emerged as a possible threat to this strategy (Menasché et al. 2003). Hence, cell transplantation is likely to be more efficacious with cells that are (or can become) cardiac myocytes themselves.

\section{Luring cells to a cardiac fate}

An alternative approach for cardiac repair is to convert noncardiac cells to a cardiac cell fate. In principle, this could occur through the transdifferentiation of cardiac fibroblasts, which comprise most of the cells of the myocardium, or through the generation of cardiac myocytes from multipotential stem cells in vitro, followed by cel- 
lular transplantation. Mouse ES cells can give rise efficiently to cardiac myocytes in culture (Doetschman et al. 1985; Robbins et al. 1990). This property has been useful for testing of candidate factors that might regulate entry into a cardiogenic pathway: leukemia inhibitory factor as a repressor (Bader et al. 2001), RA as an inducer (Wobus et al. 1997). The use of cardiac-restricted promoters to express selectable markers has also enabled the isolation of purified populations of cardiac muscle cells from this infinitely renewable source (Klug et al. 1996). The feasibility of generating rhythmically beating cardiomyocytes from human ES cells has also been substantiated (Kehat et al. 2001).

Less expected was the evidence now accumulating that adult, somatic cells might be recruited to the cardiomyocyte lineage (Fig. 5). The largest body of work deals with bone marrow-derived cells of several kinds. Despite their very low prevalence (500 per million total bone marrow cells), the so-called "side population" (SP) of CD34- ${ }^{-}-\mathrm{Kit}^{+}$cells, designated on the basis of Hoechst dye efflux, account for the majority of long-term selfrenewing hematopoietic stem cells, and can reconstitute all of the hematopoietic lineages in mice (Goodell et al. 1996). Transplanting adult bone marrow SP cells marked by lacZ expression into lethally irradiated recipients demonstrated the recruitment of lacZ-positive marrowderived cells into vascular endothelium and cardiomyocytes, after coronary artery occlusion (Jackson et al. 2001). Homing and stable engraftment under these conditions occurred specifically at the border between infarcted and normal myocardium, and was never seen in the absence of injury. Although the molecular cues that guide homing from the marrow compartment remain to be proven, it is worth noting that the infarct "border zone" preferentially expresses numerous chemotactic signals, including cytokines and adhesion molecules (Dewald et al. 2003). From a purely developmental perspective, it is intriguing that marrow-derived SP cells, although lacking markers of differentiated endothelium (factor VIII, VE-cadherin, factor VIII) and of endothelial progenitor cells (vascular-endothelial growth factor receptors), express high levels of angiopoietin-1, its receptor Tie-2, VEGF-A, and platelet-endothelial cell adhesion molecule-1 (PECAM-1, CD31; Jackson et al. 2001). Many of these features are reminiscent of the hemangioblast, a progenitor shared by hematopoietic and endothelial cells during embryogenesis (Minasi et al. 2002).

From a therapeutic perspective, the rate for engraftment directly from bone marrow into myocardium $(0.02 \%$ of all cardiomyocytes) was exciting as proof of a
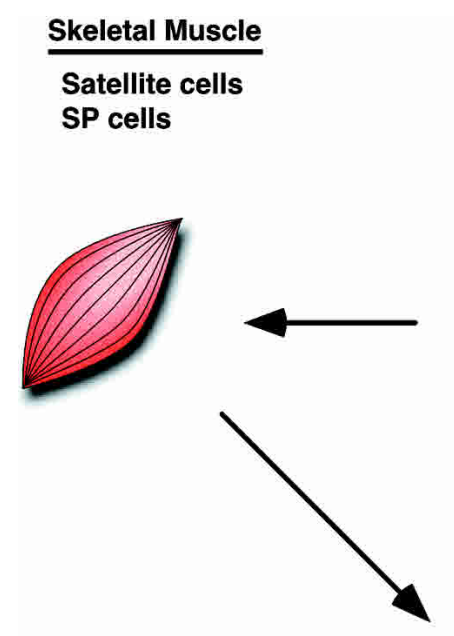
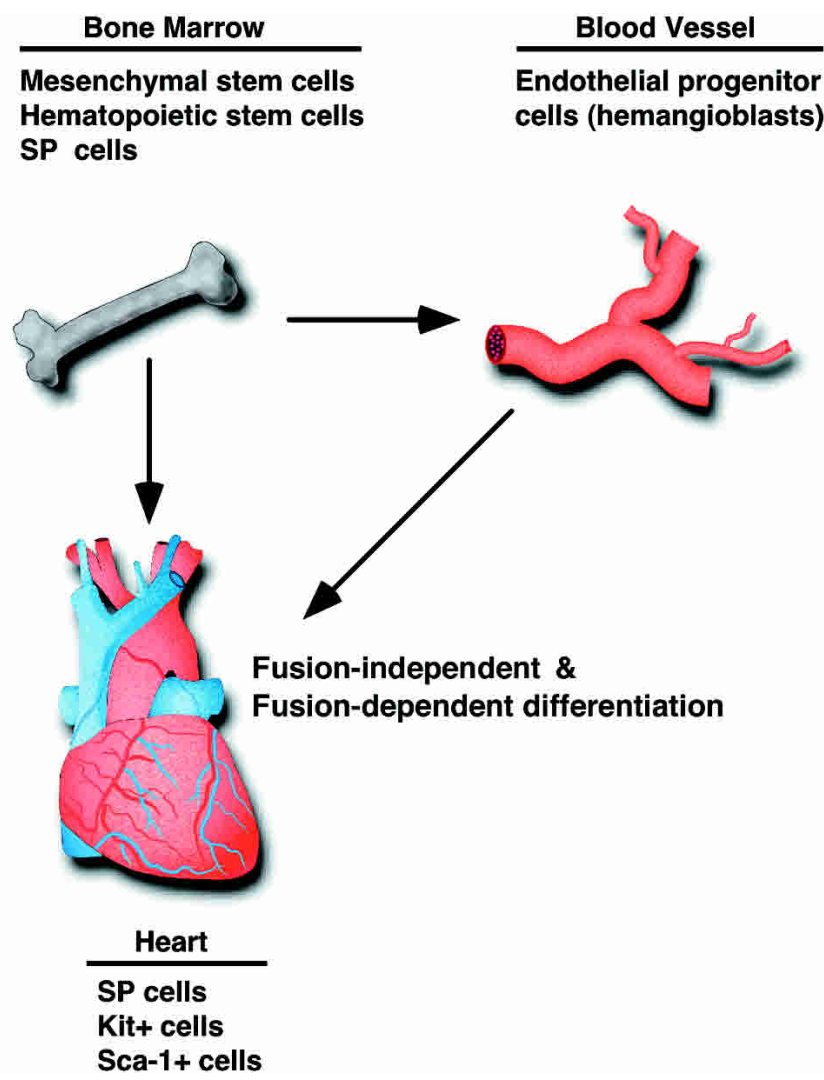

Figure 5. Stem cells intrinsic to different tissues and their transport between tissues. Intrinsic progenitor cells are shown for each of the four tissues. Arrows to the heart denote human clinical trials, now underway, using skeletal myoblasts (Menasché et al. 2003), bone marrow cells (Strauer et al. 2002; Stamm et al. 2003), and endothelial progenitor cells (Assmus et al. 2002) for cardiac repair. Arrows from bone marrow denote its role as a source of skeletal muscle SP cells (McKinney-Freeman et al. 2002), endothelial progenitor cells (Takahashi et al. 1999), and cardiomyocytes (Jackson et al. 2001). 
novel biology, but unlikely to comprise effective regeneration on its own (Jackson et al. 2001). Hence, augmenting the marrow-derived stem cells in number or state of activation could be logical. In one such study, c-Kit ${ }^{+}$ bone marrow cells were injected directly into the ventricular wall of mice adjacent to the infarct, resulting in migration into the damaged region, differentiation into cardiomyocytes and vascular cells, and partial replacement of the necrotic myocardium (Orlic et al. 2001a). The complementary strategy of mobilizing endogenous marrow-derived cells was also reportedly effective, using stem cell factor plus granulocyte-colony stimulating factor (Orlic et al. 2001b). The therapeutic appeal of this approach would be limited if removal of the spleen were necessary clinically, as was done for these experiments. Nevertheless, this finding points to the potential to mobilize and recruit circulating progenitors to the injured heart.

Adult bone marrow also contains mesenchymal stem cells, which differentiate into many mesenchymal tissue types, such as bone, marrow stroma, cartilage, tendons, ligaments, fat, and skeletal muscle. These marrow-derived stromal cells, lacking hematopoietic markers like CD34 and CD45, were found to contain high levels of telomerase and to have multilineage potential even as clonal cells (Pittenger et al. 1999). When injected into the left ventricular cavity of immunodeficient SCID mice, human mesenchymal stem cells were found chiefly in the liver, spleen, and lungs, but low levels of engraftment were seen in myocardium, with expression of many cardiac contractile proteins, cross-striations indicative of sarcomere organization, and the cardiac-specific regulator of calcium uptake into sarcoplasmic reticulum (Toma et al. 2002). More prevalent engraftment by these cells occurred when directly injected into the injured ventricular wall in pigs, after acute ischemic damage (Shake et al. 2002).

Endothelial cells, or at least their less differentiated progenitors, offer a different source for adult cardiomyocytes. Endothelial cells from the mouse dorsal aorta at E9 were grown as clonal isolates, fluorescently labeled with replication-defective lentivirus, and cocultured with neonatal rat cardiomyocytes (Condorelli et al. 2001). After 5 d, 10\% of the fluorescent cells were positive for sarcomeric myosin heavy chains and cardiac troponin-I. Similar conclusions were reached using human umbilical vein endothelial cells, including the transient coexpression of sarcomeric myosin and von Willebrand factor (Condorelli et al. 2001). Interestingly, most of the double-labeled cells were contiguous with cardiomyocytes; cardiomyocyte-conditioned medium did not induce conversion, suggesting that cell-cell contact might be needed.

Analogously, adult human endothelial progenitor cells, derived from peripheral blood mononuclear cells, also were reported to convert into cardiomyocytes on coculture with rat cardiomyocytes, as did $\mathrm{CD} 34^{+}$hematopoietic progenitor cells (Badorff et al. 2003). Because even killed cardiomyocytes were sufficient for this instructive signal and because conditioned medium was not, the best inference is a requirement for cell-cell contact or, alternatively, a secreted signal that remains associated with the extracellular matrix.

Based on these summarized experimental data, multiple clinical trials have been initiated using bone marrow-derived cells or endothelial progenitor cells for cardiac repair. Initial experience has been reported already for several of these (Assmus et al. 2002; Strauer et al. 2002; Hagege et al. 2003; Stamm et al. 2003; Tse et al. 2003), although the emphasis at this early stage has been necessarily to prove safety, not effectiveness.

\section{Driving cardiac myogenesis in therapeutic settings}

Currently, much more is known about which cells have cardiogenic potential for cardiac cell grafting than about what actual cues or pathways guide the cells' specification (or respecification, if already differentiated). It is, for example, unclear whether the same signals that specify cardiac cell fate in the early embryo (e.g., BMP's, antiWnts or Wnts) would also suffice in the adult context of cardiac "neogenesis". In a noteworthy early example of what the future can be hoped to bring (Behfar et al. 2002), paracrine pathways have been dissected for mouse ES cell conversion to the cardiac phenotype. In culture, cardiogenesis was responsive to exogenous TGF- $\beta$ or BMP2, promoted by coculture of the ES cells with cardiomyocytes and abolished by latency-associated peptide and noggin, inhibitors of TGF- $\beta$ and BMPs, respectively. Although alternative targets for the inhibitors should be considered, this implicates TGF- $\beta$ and BMPs as cardiogenic paracrine signals from differentiated myocytes. This conclusion was next tested in vivo, after cardiac grafting with ES cells bearing a heart-specific cyan fluorescent protein gene: cardiogenic differentiation in situ was prevented by both noggin and by a dominant-negative TGF- $\beta$ receptor (Behfar et al. 2002).

The notion of cellular plasticity is subject to several important caveats, reviewed in recent publications (Anderson et al. 2001; Blau et al. 2001; Seale et al. 2001; Verfaillie 2002).

\section{Cardiac progenitor cells from adult hearts}

Although cardiac muscle has not been thought to harbor a tissue-resident progenitor cell population akin to skeletal muscle satellite cells (Seale et al. 2001), recent studies have suggested the existence of a population of "immature" cardiac myocytes that may be activated in response to injury and recruited for tissue repair. One route to the discovery of candidate cells and molecules for this role in myocardium has been efflux of Hoechst dye 33342 , as used to denote SP cells in bone marrow (Asakura and Rudnicki 2002; Hierlihy et al. 2002), or expression of the responsible ATP-binding cassette transport proteins (Martin et al. 2003). A second is the use of stem cell surface markers: for instance, a c-kit ${ }^{+}$ population from adult heart migrates into the central area of necrosis, expresses cardiac differentiation mark- 
ers, and improves mechanical function when injected into injured myocardium (Bartucchi et al. 2002). Alternatively, it may be possible to mobilize such cells to damaged myocardium from their niche within the healthy heart, using suitable cytokines or chemokines.

Telomerase has provided a third means of identifying progenitor cells within adult myocardium $(\mathrm{Oh}$ et al. 2003). Down-regulation of TERT occurs in the myocardium after birth, whereas forced expression of TERT is sufficient to prolong cardiac myocyte cycling (Oh et al. 2001) and confer protection from stress-induced telomere erosion and apoptosis (Oh et al. 2003). The small but measurable residual telomerase activity in normal adult hearts prompts the question of whether a telomerase-positive subpopulation exists. If so, do such cells have cardiogenic potential, and what mechanisms might be involved in their recruitment to the cardiac differentiation pathway?

Telomerase activity in adult hearts was found to be localized to small interstitial cells expressing stem cell antigen-1 (Sca-1), which lacked the hallmarks of either hematopoietic stem cells (c-kit, CD45, CD34) or endothelial progenitor cells (CD45, CD34, Flk-1, Flt-1; Oh et al. 2003). Although purified cardiac Sca- $1^{+}$cells fail to express cardiac structural proteins, they express many cardiogenic transcription factors. Using a Cre/Lox donor/recipient pair, cardiac Sca- $1^{+}$cells were shown to home specifically to infarcted myocardium and to differentiate in situ. Half the donor-derived cardiomyocytes arose autonomously of fusion with endogenous myocytes, but half were chimeric, indicating fusion had occurred. Such findings reinforce the importance of analyzing both modes of differentiation after grafting, as has been seen in other systems (Medvinsky and Smith 2003). The molecular circuitry for cardiogenesis has begun to be dissected in this system, which might both overlap or differ from normal development in its details. However, as in virtually all developmental systems, at least a partial requirement for BMPs exists.

\section{Regulating the cardiac cell cycle}

From an applied perspective, how might fundamental knowledge of heart muscle cells' development be exploited to enhance progenitor cells' number, stable engraftment, differentiation, or function? One appealing and logical approach is to delay terminal differentiation and promote cardiomyocyte cycling, controllably. Tumor suppressor "pocket proteins," of which the retinoblastoma gene product is the founding and best-studied member, are thought to mediate terminal differentiation and growth arrest (Novitch et al. 1999; MacLellan and Schneider 2000; Pasumarthi and Field 2002). Recently, it has been possible to create cardiomyocyte lines from ventricular myocardium, by conditional (Cre-deletable) expression of SV40 large T antigen under the transcriptional control of cardiac-specific elements from the Nkx2.5 gene (Rybkin et al. 2003); deletion of the transforming gene resulted in growth arrest and susceptibility to differentiating signals including BMPs. Immortalization by SV40 large $\mathrm{T}$ antigen but not a related protein, adenoviral E1A, likely depends on the ability of large $\mathrm{T}$ antigen to interfere not just with pocket proteins, but also the tumor suppressor p53 and a $\mathrm{BH} 3$-only apoptotic protein, p193 (Pasumarthi and Field 2002).

\section{Looking to the future}

In summary, the size of the heart is governed by three general mechanisms: developmental growth, hypertrophy, and regeneration. Each of these mechanisms and their associated regulatory circuits are used to varying degrees during different stages of cardiac growth, development, and disease. Despite the ability of the heart to modulate its size by these mechanisms, all of the existing endogenous mechanisms for repair, acting collectively, are obviously inadequate-when unassisted-to restore function fully to the adult heart following injury. We envision that more complete restoration of function to the injured heart, and perhaps the maintenance of cardiac function despite aging, will benefit from the exploitation of developmental control mechanisms. One set of therapeutic targets will involve strategies for increasing cardiac muscle cell number: coaxing noncardiac cells to adopt a cardiac fate, selectively amplifying the small subpopulation of immature cardiomyocytes that resides in the adult heart, or overcoming the barrier to proliferation in terminally differentiated cardiomyocytes. Lest these seem far-fetched and remote, it needs to be recalled that clinical trials implanting cells of several kinds have been implemented.

A second approach will involve strategies that suppress adverse adaptations and, perhaps, enhance the salutary ones. Indeed, molecular dissection of the intracellular circuits that couple stress signals to developmental transcription factors in the hypertrophied and failing heart have revealed nodal points currently being exploited as targets for drug discovery. Thus, a mechanistic understanding of how the heart sizes itself up during development and disease promises to yield unanticipated therapeutic targets and novel strategies for accomplishing the ambitious goals of cardiac repair and regeneration, ensuring that the beat goes on.

\section{Acknowledgments}

E.N.O. is supported by grants from the National Institutes of Health, the D.W. Reynolds Center for Clinical Cardiovascular Medicine, the Muscular Dystrophy Association, the Robert A. Welch Foundation, and the McGowan Foundation. M.D.S. is supported by grants from the National Institutes of Health and the M.D. Anderson Foundation Professorship.

\section{References}

Alsan, B.H. and Schultheiss, T.M. 2002. Regulation of avian cardiogenesis by Fgf8 signaling. Development 129: 19351943.

Anderson, D.J., Gage, F.H., and Weissman, I.L. 2001. Can stem cells cross lineage boundaries? Nat. Med. 7: 393-395. 
Antos, C.L., McKinsey, T.A., Frey, N., Kutschke, W., McAnally, J., Shelton, J.M., Richardson, J.A., Hill, J.A., and Olson, E.N. 2002. Activated glycogen synthase-3 $\beta$ suppresses cardiac hypertrophy in vivo. Proc. Natl. Acad. Sci. 99: 907-912.

Antos, C.L., McKinsey, T.A., Dreitz, M., Hollingsworth, L.M., Zhang, C.-L., Schreiber, K., Rindt, H., Gorczynski, R.J., and Olson, E.N. 2003. Dose-dependent blockade to cardiomyocyte hypertrophy by histone deacetylase inhibitors. J. Biol. Chem. (in press).

Arsenian, S., Weinhold, B., Oelgeschlager, M., Ruther, U., and Nordheim, A. 1998. Serum response factor is essential for mesoderm formation during mouse embryogenesis. EMBO $J$. 17: 6289-6299.

Asakura, A. and Rudnicki, M.A. 2002. Side population cells from diverse adult tissues are capable of in vitro hematopoietic differentiation. Exp. Hematol. 30: 1339-1345.

Assmus, B., Schachinger, V., Teupe, C., Britten, M., Lehmann, R., Dobert, N., Grunwald, F., Aicher, A., Urbich, C., Martin, H., et al. 2002. Transplantation of progenitor cells and regeneration enhancement in acute myocardial infarction (TOPCARE-AMI). Circulation 106: 3009-3017.

Bader, A., Gruss, A., Hollrigl, A., Al-Dubai, H., Capetanaki, Y., and Weitzer, G. 2001. Paracrine promotion of cardiomyogenesis in embryoid bodies by LIF modulated endoderm. Differentiation 68: $31-43$.

Badorff, C., Brandes, R.P., Popp, R., Rupp, S., Urbich, C., Aicher, A., Fleming, I., Busse, R., Zeiher, A.M., and Dimmeler, S. 2003. Transdifferentiation of blood-derived human adult endothelial progenitor cells into functionally active cardiomyocytes. Circulation 107: 1024-1032.

Barron, M., Gao, M., and Lough, J. 2000. Requirement for BMP and FGF signaling during cardiogenic induction in non-precardiac mesoderm is specific, transient, and cooperative. Dev. Dyn. 218: 383-393.

Bartucchi, L., Chimenti, S., Jakoniuk, I., Mancarella, S., Musso, E., Beltrami, A.P., Zacheo, A., Leri, A., Nadal-Ginard, B., Anversa, P., et al. 2002. The injection of c-kit-derived cardiac lineages in vitro repairs infarcted scarred myocrdium in vivo. Circulation 106: II-130.

Basson, C.T., Huang, T.S., Lin, R.C., Bachinsky, D.R., Weremowicz, S., Vaglio, A., Bruzzone, R., Quadrelli, R., Lerone, M., Romeo, G., et al. 1999. Different TBX5 interactions in heart and limb defined by Holt-Oram syndrome mutations. Proc. Natl. Acad. Sci. 96: 2919-2924.

Behfar, A., Zingman, L.V., Hodgson, D.M., Rauzier, J.M., Kane, G.C., Terzic, A., and Puceat, M. 2002. Stem cell differentiation requires a paracrine pathway in the heart. FASEB $J$. 16: $1558-1566$.

Belaguli, N.S., Sepulveda, J.L., Nigam, V., Charron, F., Nemer, M., and Schwartz, R.J. 2000. Cardiac tissue enriched factors serum response factor and GATA-4 are mutual coregulators. Mol. Cell. Biol. 20: 7550-7558.

Biben, C. and Harvey, R.P. 1997. Homeodomain factor Nkx2-5 controls left/right asymmetric expression of bHLH gene eHand during murine heart development. Genes \& Dev. 11: $1357-1369$.

Blackburn, E.H. 2001. Switching and signaling at the telomere. Cell 106: 661-673.

Blankenhorn, E.P., Troutman, S., Clark, L.D., Zhang, X.M., Chen, P., and Heber-Katz, E. 2003. Sexually dimorphic genes regulate healing and regeneration in MRL mice. Mamm. Genome 14: 250-260.

Blasco, M.A., Lee, H.W., Rizen, M., Hanahan, D., DePinho, R., and Greider, C.W. 1997. Mouse models for the study of telomerase. Ciba Found. Symp. 211: 160-170.

Blau, H.M., Brazelton, T.R., and Weimann, J.M. 2001. The evolving concept of a stem cell: Entity or function? Cell 105: 829-841.

Bodine, S.C., Stitt, T.N., Gonzalez, M., Kline, W.O., Stover, G.L., Bauerlein, R., Zlotchenko, E., Scrimgeour, A., Lawrence, J.C., Glass, D.J., et al. 2001. Akt/mTOR pathway is a crucial regulator of skeletal muscle hypertrophy and can prevent muscle atrophy in vivo. Nat. Cell Biol. 3: 10141019.

Boluyt, M.O., Zheng, J.S., Younes, A., Long, X., O'Neill, L., Silverman, H., Lakatta, E.G., and Crow, M.T. 1997. Rapamycin inhibits $\alpha$ 1-adrenergic receptor-stimulated cardiac myocyte hypertrophy but not activation of hypertrophy-associated genes. Evidence for involvement of p70 S6 kinase. Circ. Res. 81: 176-186.

Bonilla, M., Nastase, K.K., and Cunningham, K.W. 2002. Essential role of calcineurin in response to endoplasmic reticulum stress. EMBO J. 21: 2343-2353.

Bour, B.A., O’Brien, M.A., Lockwood, W.L., Goldstein, E.S., Bodmer, R., Taghert, P.H., Abmayr, S.M., and Nguyen, H.T. 1995. Drosophila MEF2, a transcription factor that is essential for myogenesis. Genes \& Dev. 9: 730-741.

Brockes, J.P. and Kumar, A. 2002. Plasticity and reprogramming of differentiated cells in amphibian regeneration. Nat. Rev. Mol. Cell Biol. 3: 566-574.

Bruneau, B.G., Logan, M., Davis, N., Levi, T., Tabin, C.J., Seidman, J.G., and Seidman, C.E. 1999. Chamber-specific cardiac expression of Tbx5 and heart defects in Holt-Oram syndrome. Dev. Biol. 211: 100-108.

Bruneau, B.G., Nemer, G., Schmitt, J.P., Charron, F., Robitaille, L., Caron, S., Conner, D.A, Gessler, M., Nemer, M., Seidman, C.E., et al. 2001. A murine model of Holt-Oram syndrome defines roles of the T-box transcription factor Tbx5 in cardiogenesis and disease. Cell 106: 709-721.

Cantley, L.C. 2002. The phosphoinositide 3-kinase pathway. Science 296: 1655-1657.

Chang, D.F., Belaguli, N.S., Iyer, D., Roberts, W.B., Wu, S.P., Dong, X.R., Marx, J.G., Moore, M.S., Beckerle, M.C., Majesky, M.W., et al. 2003. Cysteine-rich LIM-only proteins CRP1 and CRP2 are potent smooth muscle differentiation cofactors. Dev. Cell 4: 107-118.

Charite, J., McFadden, D.G., and Olson, E.N. 2000. The bHLH transcription factor dHAND controls Sonic hedgehog expression and establishment of the zone of polarizing activity during limb development. Development 127: 2461-2470.

Chen, J.N. and Fishman, M.C. 1996. Zebrafish tinman homolog demarcates the heart field and initiates myocardial differentiation. Development 122: 3809-3816.

Chen, C.Y. and Schwartz, R.J. 1996. Recruitment of the tinman homolog Nkx-2.5 by serum response factor activates cardiac $\alpha$-actin gene transcription. Mol. Cell. Biol. 16: 6372-6384.

Chen, J., Kubalak, S.W., and Chien, K.R. 1998. Ventricular muscle-restricted targeting of the $\operatorname{RXR} \alpha$ gene reveals a noncell-autonomous requirement in cardiac chamber morphogenesis. Development 125: 1943-1949.

Chen, F., Kook, H., Milewski, R., Gitler, A.D., Lu, M.M., Li, J., Nazarian, R., Schnepp, R., Jen, K., Biben, C., et al. 2002. Hop is an unusual homeobox gene that modulates cardiac development. Cell 110: 713-723.

Chen, J., Kitchen, C.M., Streb, J.W., and Miano, J.M. 2002. Myocardin: A component of a molecular switch for smooth muscle differentiation. J. Mol. Cell. Cardiol. 34: 1345-1356.

Chen, T.H., Chang, T.C., Kang, J.O., Choudhary, B., Makita, T., Tran, C.M., Burch, J.B., Eid, H., and Sucov, H.M. 2002. Epicardial induction of fetal cardiomyocyte proliferation via a retinoic acid-inducible trophic factor. Dev. Biol. 250: 198207. 
Christoffels, V.M., Habets, P.E., Franco, D., Campione, M., de Jong, F., Lamers, W.H., Bao, Z.Z., Palmer, S., Biben, C., Harvey, R.P., et al. 2000. Chamber formation and morphogenesis in the developing mammalian heart. Dev. Biol. 223: 266-278.

Cleaver, O.B., Patterson, K.D., and Krieg, P.A. 1996. Overexpression of the tinman-related genes XNkx-2.5 and XNkx2.3 in Xenopus embryos results in myocardial hyperplasia. Development 122: 3549-3556.

Condorelli, G., Borello, U., De Angelis, L., Latronico, M., Sirabella, D., Coletta, M., Galli, R., Balconi, G., Follenzi, A., Frati, G., et al. 2001. Cardiomyocytes induce endothelial cells to trans-differentiate into cardiac muscle: Implications for myocardium regeneration. Proc. Natl. Acad. Sci. 98: 10733-10738.

Crabtree, G.R. and Olson, E.N. 2002. NFAT signaling: Choreographing the social lives of cells. Cell (Suppl.) 109: S67-79.

Crackower, M.A., Oudit, G.Y., Kozieradzki, I., Sarao, R., Sun, H., Sasaki, T., Hirsch, E., Suzuki, A., Shioi, T., Irie-Sasaki, J., et al. 2002. Regulation of myocardial contractility and cell size by distinct PI3K-PTEN signaling pathways. Cell 110: 737-749.

Croissant, J.D., Kim, J.H., Eichele, G., Goering, L., Lough, J., Prywes, R., and Schwartz, R.J. 1996. Avian serum response factor expression restricted primarily to muscle cell lineages is required for $\alpha$-actin gene transcription. Dev. Biol. 177: 250-264.

Crone, S.A., Zhao, Y.Y., Fan, L., Gu, Y., Minamisawa, S., Liu, Y., Peterson, K.L., Chen, J., Kahn, R., Condorelli, G., et al. 2002. ErbB2 is essential in the prevention of dilated cardiomyopathy. Nat. Med. 8: 459-465.

Delaughter, M.C., Taffet, G.E., Fiorotto, M.L., Entman, M.L., and Schwartz, R.J. 1999. Local insulin-like growth factor I expression induces physiologic, then pathologic, cardiac hypertrophy in transgenic mice. FASEB J. 13: 1923-1929.

Dewald, O., Frangogiannis, N.G., Zoerlein, M., Duerr, G.D., Klemm, C., Knuefermann, P., Taffet, G., Michael, L.H., Crapo, J.D., Welz, A., et al. 2003. Development of murine ischemic cardiomyopathy is associated with a transient inflammatory reaction and depends on reactive oxygen species. Proc. Nat1. Acad. Sci. 100: 2700-2705.

Ding, J., Yang, L., Yan, Y.T., Chen, A., Desai, N., WynshawBoris, A., and Shen, M.M. 1998. Cripto is required for correct orientation of the anterior-posterior axis in the mouse embryo. Nature 395: 702-707.

Doetschman, T.C., Eistetter, H., Katz, M., Schmidt, W., and Kemler, R. 1985. The in vitro development of blastocystderived embryonic stem cell lines: Formation of visceral yolk sac, blood islands, and myocardium. J. Embryol. Exp. Morphol. 87: 27-45.

Du, K.L., Ip, H.S., Li, J., Chen, M., Dandre, F., Yu, W., Lu, M.M., Owens, G.K., and Parmacek, M.S. 2003. Myocardin is a critical serum response factor cofactor in the transcriptional program regulating smooth muscle cell differentiation. Mol. Cell. Biol. 23: 2425-237.

Eisenberg, C.A. and Eisenberg, L.M. 1999. WNT11 promotes cardiac tissue formation of early mesoderm. Dev. Dyn. 216: $45-58$.

Eisenberg, C.A., Gourdie, R.G., and Eisenberg, L.M. 1997. Wnt11 is expressed in early avian mesoderm and required for the differentiation of the quail mesoderm cell line QCE-6. Development 124: 525-536.

Evans, S.M., Yan, W., Murillo, M.P., Ponce, J., and Papalopulu, N. 1995. tinman, a Drosophila homeobox gene required for heart and visceral mesoderm specification, may be represented by a family of genes in vertebrates: XNkx-2.3, a sec- ond vertebrate homologue of tinman. Development 121: 3889-3899.

Firulli, A.B., McFadden, D.G., Lin, Q., Srivastava, D., and Olson, E.N. 1998. Heart and extra-embryonic mesodermal defects in mouse embryos lacking the bHLH transcription factor Hand1. Nat. Genet. 18: 266-270.

Fishman, M.C. and Chien, K.R. 1997. Fashioning the vertebrate heart: Earliest embryonic decisions. Development 124: 2099-2117.

Fishman, M.C. and Olson, E.N. 1997. Parsing the heart: Genetic modules for organ assembly. Cell 91: 153-156.

Frey, N., McKinsey, T.A., and Olson, E.N. 2000a. Decoding calcium signals involved in cardiac growth and function. Nat. Med. 6: 1221-1227.

Frey, N., Richardson, J.A., and Olson, E.N. 2000b. Calsarcins, a novel family of sarcomeric calcineurin-binding proteins. Proc. Nat1. Acad. Sci. 97: 14632-14637.

Garratt, A.N., Ozcelik, C., and Birchmeier, C. 2003. ErbB2 pathways in heart and neural diseases. Trends Cardiovasc. Med. 13: $80-86$.

Gassmann, M., Casagranda, F., Orioli, D., Simon, H., Lai, C., Klein, R., and Lemke, G. 1995. Aberrant neural and cardiac development in mice lacking the ErbB4 neuregulin receptor. Nature 378: 390-394.

Gaussin, V., Van De Putte, T., Mishina, Y., Hanks, M.C., Zwijsen, A., Huylebroeck, D., Behringer, R.R., and Schneider, M.D. 2002. Endocardial cushion and myocardial defects after cardiac myocyte-specific conditional deletion of the bone morphogenetic protein receptor ALK3. Proc. Natl. Acad. Sci. 99: $2878-2883$.

Gingras, A.C., Raught, B., and Sonenberg, N. 2001. Regulation of translation initiation by FRAP/mTOR. Genes \& Dev. 15: $807-826$.

Gisselbrecht, S., Skeath, J.B., Doe, C.Q., and Michelson, A.M. 1996. heartless encodes a fibroblast growth factor receptor (DFR1/DFGF-R2) involved in the directional migration of early mesodermal cells in the Drosophila embryo. Genes \& Dev. 10: 3003-3017.

Goodell, M.A., Brose, K., Paradis, G., Conner, A.S., and Mulligan, R.C. 1996. Isolation and functional properties of murine hematopoietic stem cells that are replicating in vivo. J. Exp. Med. 183: 1797-1806.

Gottlieb, P.D., Pierce, S.A., Sims, R.J., Yamagishi, H., Weihe, E.K., Harriss, J.V., Maika, S.D., Kuziel, W.A., King, H.L., Olson, E.N., et al. 2002. Bop encodes a muscle-restricted protein containing MYND and SET domains and is essential for cardiac differentiation and morphogenesis. Nat. Genet. 31: 25-32.

Gourevitch, D., Clark, L., Chen, P., Seitz, A., Samulewicz, S.J., and Heber-Katz, E. 2003. Matrix metalloproteinase activity correlates with blastema formation in the regenerating MRL mouse ear hole model. Dev. Dyn. 226: 377-387.

Griffin, K.J. and Kimelman, D. 2002. One-Eyed Pinhead and Spadetail are essential for heart and somite formation. Nat. Cell Biol. 4: 821-825.

Gritsman, K., Zhang, J., Cheng, S., Heckscher, E., Talbot, W.S., and Schier, A.F. 1999. The EGF-CFC protein one-eyed pinhead is essential for nodal signaling. Cell 97: 121-132.

Hagege, A.A., Carrion, C., Menasché, P., Vilquin, J.T., Duboc, D., Marolleau, J.P., Desnos, M., and Bruneval, P. 2003. Viability and differentiation of autologous skeletal myoblast grafts in ischaemic cardiomyopathy. Lancet 361: 491-492.

Harvey, R.P. 2002. Patterning the vertebrate heart. Nat. Rev. Genet. 3: 544-556.

Harwood, A.J. 2001. Regulation of GSK-3: A cellular multiprocessor. Cell 105: 821-824. 
Hierlihy, A.M., Seale, P., Lobe, C.G., Rudnicki, M.A., and Megeney, L.A. 2002. The post-natal heart contains a myocardial stem cell population. FEBS Lett. 530: 239-243.

Horb, M.E. and Thomsen, G.H. 1999. Tbx5 is essential for heart development. Development 126: 1739-1751.

Horsley, V., Jansen, K.M., Mills, S.T., and Pavlath, G.K. 2003. IL-4 acts as a myoblast recruitment factor during mammalian muscle growth. Cell 113: 483-494.

Hove, J.R., Koster, R.W., Forouhar, A.S., Acevedo-Bolton, G., Fraser, S.E., and Gharib, M. 2003. Intracardiac fluid forces are an essential epigenetic factor for embryonic cardiogenesis. Nature 421: 172-177.

Hunter, J.J. and Chien, K.R. 1999. Signaling pathways for cardiac hypertrophy and failure. N. Engl. I. Med. 341: 12761283.

Hutcheson, K.A., Atkins, B.Z., Hueman, M.T., Hopkins, M.B., Glower, D.D., and Taylor, D.A. 2000. Comparison of benefits on myocardial performance of cellular cardiomyoplasty with skeletal myoblasts and fibroblasts. Cell Transplant. 9: 359-368.

Imokawa, Y. and Brockes, J.P. 2003. Selective activation of thrombin is a critical determinant for vertebrate lens regeneration. Curr. Biol. 13: 877-881.

Jackson, K.A., Majka, S.M., Wang, H., Pocius, J., Hartley, C.J., Majesky, M.W., Entman, M.L., Michael, L.H., Hirschi, K.K., and Goodell, M.A. 2001. Regeneration of ischemic cardiac muscle and vascular endothelium by adult stem cells. J. Clin. Invest. 107: 1395-1402.

Kang, P.M. and Izumo, S. 2003. Apoptosis in heart: Basic mechanisms and implications in cardiovascular diseases. Trends Mol. Med. 9: 177-182.

Kastner, P., Messaddeq, N., Mark, M., Wendling, O., Grondona, J.M., Ward, S., Ghyselinck, N., and Chambon, P. 1997. Vitamin A deficiency and mutations of $\operatorname{RXR} \alpha, \operatorname{RXR} \beta$ and $\mathrm{RAR} \alpha$ lead to early differentiation of embryonic ventricular cardiomyocytes. Development 124: 4749-4758.

Kaufman, M.H. 1992. The atlas of mouse development, pp. 442. Academic Press, London.

Kawamoto, A., Tkebuchava, T., Yamaguchi, J., Nishimura, H., Yoon, Y.S., Milliken, C., Uchida, S., Masuo, O., Iwaguro, H., $\mathrm{Ma}, \mathrm{H}$., et al. 2003. Intramyocardial transplantation of autologous endothelial progenitor cells for therapeutic neovascularization of myocardial ischemia. Circulation 107: 461468.

Kehat, I., Kenyagin-Karsenti, D., Snir, M., Segev, H., Amit, M., Gepstein, A., Livne, E., Binah, O., Itskovitz-Eldor, J., and Gepstein, L. 2001. Human embryonic stem cells can differentiate into myocytes with structural and functional properties of cardiomyocytes. J. Clin. Invest. 108: 407-414.

Klug, M.G., Soonpaa, M.H., Koh, G.Y., and Field, L.J. 1996. Genetically selected cardiomyocytes from differentiating embryonic stem cells form stable intracardiac grafts. J. Clin. Invest. 98: 216-224.

Kocher, A.A., Schuster, M.D., Szabolcs, M.J., Takuma, S., Burkhoff, D., Wang, J., Homma, S., Edwards, N.M., and Itescu, S. 2001. Neovascularization of ischemic myocardium by human bone-marrow-derived angioblasts prevents cardiomyocyte apoptosis, reduces remodeling and improves cardiac function. Nat. Med. 7: 430-436.

Koh, G.Y., Soonpaa, M.H., Klug, M.G., Pride, H.P., Cooper, B.J., Zipes, D.P., and Field, L.J. 1995. Stable fetal cardiomyocyte grafts in the hearts of dystrophic mice and dogs. J. Clin. Invest. 96: 2034-2042.

Krishnan, P., King, M.W., Neff, A.W., Sandusky, G.E., Bierman, K.L., Grinnell, B., and Smith, R.C. 2001. Human truncated Smad 6 (Smad 6s) inhibits the BMP pathway in Xenopus laevis. Dev. Growth Differ. 43: 115-132.

Kuo, C.T., Morrisey, E.E., Anandappa, R., Sigrist, K., Lu, M.M., Parmacek, M.S., Soudais, C., and Leiden, J.M. 1997. GATA4 transcription factor is required for ventral morphogenesis and heart tube formation. Genes \& Dev. 11: 1048-1060.

Lai, K.M. and Pawson, T. 2000. The ShcA phosphotyrosine docking protein sensitizes cardiovascular signaling in the mouse embryo. Genes \& Dev. 14: 1132-1145.

Lee, K.F., Simon, H., Chen, H., Bates, B., Hung, M.C., and Hauser, C. 1995. Requirement for neuregulin receptor erbB2 in neural and cardiac development. Nature 378: 394-398.

Leferovich, J.M., Bedelbaeva, K., Samulewicz, S., Zhang, X.M., Zwas, D., Lankford, E.B., and Heber-Katz, E. 2001. Heart regeneration in adult MRL mice. Proc. Natl. Acad. Sci. 98: 9830-9835.

Leinwand, L.A. 2001. Calcineurin inhibition and cardiac hypertrophy: A matter of balance. Proc. Natl. Acad. Sci. 98: 29472949.

Leri, A., Franco, S., Zacheo, A., Barlucchi, L., Chimenti, S., Limana, F., Nadal-Ginard, B., Kajstura, J., Anversa, P., and Blasco, M.A. 2003. Ablation of telomerase and telomere loss leads to cardiac dilatation and heart failure associated with p53 upregulation. EMBO J. 22: 131-139.

Levin, M., Thorlin, T., Robinson, K.R., Nogi, T., and Mercola, M. 2002. Asymmetries in $\mathrm{H}+/ \mathrm{K}+-A T P a s e$ and cell membrane potentials comprise a very early step in left-right patterning. Cell 111: 77-89.

Liang, Q., Wiese, R.J., Bueno, O.F., Dai, Y.S., Markham, B.E., and Molkentin, J.D. 2001. The transcription factor GATA4 is activated by extracellular signal-regulated kinase 1- and 2-mediated phosphorylation of serine 105 in cardiomyocytes. Mol. Cell. Biol. 21: 7460-7469.

Lickert, H., Kutsch, S., Kanzler, B., Tamai, Y., Taketo, M.M., and Kemler, R. 2002. Formation of multiple hearts in mice following deletion of $\beta$-catenin in the embryonic endoderm. Dev. Cell. 3: 171-181.

Lien, C.L., Wu, C., Mercer, B., Webb, R., Richardson, J.A., and Olson, E.N. 1999. Control of early cardiac-specific transcription of Nkx2-5 by a GATA-dependent enhancer. Development 126: 75-84.

Lilly, B., Zhao, B., Ranganayakulu, G., Paterson, B.M., Schulz, R.A., and Olson, E.N. 1995. Requirement of MADS domain transcription factor D-MEF2 for muscle formation in Drosophila. Science 267: 688-693.

Lin, Q., Schwarz, J., Bucana, C., and Olson, E.N. 1997. Control of mouse cardiac morphogenesis and myogenesis by transcription factor MEF2C. Science 276: 1404-147.

Lints, T.J., Parsons, L.M., Hartley, L., Lyons, I., and Harvey, R.P. 1993. Nkx-2.5: A novel murine homeobox gene expressed in early heart progenitor cells and their myogenic descendants. Development 119: 969.

Lough, J., Barron, M., Brogley, M., Sugi, Y., Bolender, D.L., and Zhu, X. 1996. Combined BMP-2 and FGF-4, but neither factor alone, induces cardiogenesis in non-precardiac embryonic mesoderm. Dev. Biol. 178: 198-202.

Lu, J., McKinsey, T.A., Nicol, R.L., and Olson, E.N. 2000. Signal-dependent activation of the MEF2 transcription factor by dissociation from histone deacetylases. Proc. Natl. Acad. Sci. 97: 4070-4075.

Lyons, I., Parsons, L.M., Hartley, L., Li, R., Andrews, J.E., Robb, L., and Harvey, R.P. 1995. Myogenic and morphogenetic defects in the heart tubes of murine embryos lacking the homeo box gene Nkx2-5. Genes \& Dev. 9: 1654-1666.

MacLellan, W.R. and Schneider, M.D. 2000. Genetic dissection of cardiac growth control pathways. Annu. Rev. Physiol. 62: 289-320. 
Martin, C.M., Meeson, A.P., Robertson, S., Richardson, J., Bates, S., Gallardo T., and Garry D.J. 2003. Persistent expression of the ATP-cassette transporter, Abcg2, identifies cardiac stem cells in the adult heart. In From stem cells to therapy. Keystone Symposia, Steamboat Springs, CO.

Marvin, M.J., Di Rocco, G., Gardiner, A., Bush, S.M., and Lassar, A.B. 2001. Inhibition of Wnt activity induces heart formation from posterior mesoderm. Genes \& Dev. 15: 316-327.

McBrearty, B.A., Clark, L.D., Zhang, X.M., Blankenhorn, E.P., and Heber-Katz, E. 1998. Genetic analysis of a mammalian wound-healing trait. Proc. Natl. Acad. Sci. 95: 11792-11797.

McFadden, D.G., Charite, J., Richardson, J.A., Srivastava, D., Firulli, A.B., and Olson, E.N. 2000. A GATA-dependent right ventricular enhancer controls dHAND transcription in the developing heart. Development 127: 5331-5341.

McGann, C.J., Odelberg, S.J., and Keating, M.T. 2001. Mammalian myotube dedifferentiation induced by newt regeneration extract. Proc. Natl. Acad. Sci. 98: 13699-13704.

McKinney-Freeman, S.L., Jackson, K.A., Camargo, F.D., Ferrari, G., Mavilio, F., and Goodell, M.A. 2002. Muscle-derived hematopoietic stem cells are hematopoietic in origin. Proc. Natl. Acad. Sci. 99: 1341-1346.

McKinsey, T.A., Zhang, C.L., Lu, J., and Olson, E.N. 2000. Signal-dependent nuclear export of a histone deacetylase regulates muscle differentiation. Nature 408: 106-111.

McKinsey, T.A., Zhang, C.L., and Olson, E.N. 2002. MEF2: A calcium-dependent regulator of cell division, differentiation and death. Trends Biochem. Sci. 27: 40-47.

Medvinsky, A. and Smith, A. 2003. Stem cells: Fusion brings down barriers. Nature 422: 823-825.

Menasché, P., Hagege, A.A., Vilquin, J.T., Desnos, M., Abergel, E., Pouzet, B., Bel, A., Sarateanu, S., Scorsin, M., Schwartz, K., et al. 2003. Autologous skeletal myoblast transplantation for severe postinfarction left ventricular dysfunction. J. Am. Coll. Cardiol. 41: 1078-1083.

Mikawa, T., Borisov, A., Brown, A.M., and Fischman, D.A. 1992. Clonal analysis of cardiac morphogenesis in the chicken embryo using a replication-defective retrovirus. I. Formation of the ventricular myocardium. Dev. Dyn. 193: $11-23$.

Minasi, M.G., Riminucci, M., De Angelis, L., Borello, U., Berarducci, B., Innocenzi, A., Caprioli, A., Sirabella, D., Baiocchi, M., De Maria, R., et al. 2002. The meso-angioblast: A multipotent, self-renewing cell that originates from the dorsal aorta and differentiates into most mesodermal tissues. Development 129: 2773-2783.

Miura, S., Tallquist, M.D., Soriano, P., and Mishina, Y. 2002. BMP signaling is important for mesoderm induction and germ layer development in mouse embryogenesis. Dev. Biol. 247: 505 .

Miyata, S., Minobe, W., Bristow, M.R., and Leinwand, L.A. 2000. Myosin heavy chain isoform expression in the failing and nonfailing human heart. Circ. Res. 86: 386-390.

Molkentin, J.D. and Dorn II, I.G. 2001. Cytoplasmic signaling pathways that regulate cardiac hypertrophy. Annu. Rev. Physiol. 63: 391-426.

Molkentin, J.D., Lin, Q., Duncan, S.A., and Olson, E.N. 1997. Requirement of the transcription factor GATA4 for heart tube formation and ventral morphogenesis. Genes \& Dev. 11: $1061-1072$.

Molkentin, J.D., Lu, J.R., Antos, C.L., Markham, B., Richardson, J., Robbins, J., Grant, S.R., and Olson, E.N. 1998. A calcineurin-dependent transcriptional pathway for cardiac hypertrophy. Cell 93: 215-228.

Molkentin, J.D., Antos, C., Mercer, B., Taigen, T., Miano, J.M., and Olson, E.N. 2000. Direct activation of a GATA6 cardiac enhancer by Nkx2.5: Evidence for a reinforcing regulatory network of Nkx2.5 and GATA transcription factors in the developing heart. Dev. Biol. 217: 301-309.

Monzen, K., Shiojima, I., Hiroi, Y., Kudoh, S., Oka, T., Takimoto, E., Hayashi, D., Hosoda, T., Habara-Ohkubo, A., Nakaoka, T., et al. 1999. Bone morphogenetic proteins induce cardiomyocyte differentiation through the mitogen-activated protein kinase kinase kinase TAK1 and cardiac transcription factors Csx/Nkx-2.5 and GATA-4. Mol. Cell. Biol. 19: 7096-7105.

Monzen, K., Hiroi, Y., Kudoh, S., Akazawa, H., Oka, T., Takimoto, E., Hayashi, D., Hosoda, T., Kawabata, M., Miyazono, K., et al. 2001. Smads, TAK1, and their common target ATF-2 play a critical role in cardiomyocyte differentiation. J. Cell Biol. 153: 687-698.

Morisco, C., Seta, K., Hardt, S.E., Lee, Y., Vatner, S.F., and Sadoshima, J. 2001. Glycogen synthase kinase $3 \beta$ regulates GATA4 in cardiac myocytes. J. Biol. Chem. 276: 2858628597.

Moss, J.B., Xavier-Neto, J., Shapiro, M.D., Nayeem, S.M., McCaffery, P., Drager, U.C., and Rosenthal, N. 1998. Dynamic patterns of retinoic acid synthesis and response in the developing mammalian heart. Dev. Biol. 199: 55-71.

Nadruz Jr., W., Kobarg, C.B., Constancio, S.S., Corat, P.D., and Franchini, K.G. 2003. Load-induced transcriptional activation of c-jun in rat myocardium: Regulation by myocyte enhancer factor 2. Circ. Res. 92: 243-251.

Nakamura, T.S., Sano, M., Songyang, Z., Schneider, M.D. 2003. A Wnt- and $\beta$-catenin-dependent pathway for mammalian cardiac myogenesis. Proc. Natl. Acad. Sci. 100: 5834-5839.

Natarajan, A., Yamagishi, H., Ahmad, F., Li, D., Roberts, R., Matsuoka, R., Hill, S., and Srivastava, D. 2001. Human eHAND, but not dHAND, is down-regulated in cardiomyopathies. J. Mol. Cell. Cardiol. 33: 1607-1614.

Naya, F.J., Black, B.L., Wu, H., Bassel-Duby, R., Richardson, J.A., Hill, J.A., and Olson, E.N. 2002. Mitochondrial deficiency and cardiac sudden death in mice lacking the MEF2A transcription factor. Nat. Med. 8: 1303-1309.

Niederreither, K., Vermot, J., Messaddeq, N., Schuhbaur, B., Chambon, P., and Dolle, P. 2001. Embryonic retinoic acid synthesis is essential for heart morphogenesis in the mouse. Development 128: 1019-1031.

Novitch, B.G., Spicer, D.B., Kim, P.S., Cheung, W.L., and Lassar, A.B. 1999. pRb is required for MEF2-dependent gene expression as well as cell-cycle arrest during skeletal muscle differentiation. Curr. Biol. 9: 449-459.

Oberpriller, J.O., Oberpriller, J.C., Matz, D.G., and Soonpaa, M.H. 1995. Stimulation of proliferative events in the adult amphibian cardiac myocyte. Ann. N.Y. Acad. Sci. 752: 3046.

Oh, H., Taffet, G.E., Youker, K.A., Entman, M.L., Overbeek, P.A., Michael, L.H., and Schneider, M.D. 2001. Telomerase reverse transcriptase promotes cardiac muscle cell proliferation, hypertrophy, and survival. Proc. Natl. Acad. Sci. 98: 10308-10313.

Oh, H., Miura, T., Bradfute, S.B., Chi, X., Entman, M.L., Michael, L.M., Schwartz, R.J., Minamino, T., Gaussin, V., Mishina, Y., et al. 2003. Cardiac homing, differentiation, and fusion by progenitor cells from adult heart. In From stem cells to therapy, p. 129. Keystone Symposia, Steamboat Springs, CO.

Olson, E.N. 2001. Development. The path to the heart and the road not taken. Science 291: 2327-2328.

Orlic, D., Kajstura, J., Chimenti, S., Jakoniuk, I., Anderson, S.M., Li, B., Pickel, J., McKay, R., Nadal-Ginard, B., Bodine, D.M., et al. 2001a. Bone marrow cells regenerate infarcted 
myocardium. Nature 410: 701-705.

Orlic, D., Kajstura, J., Chimenti, S., Limana, F., Jakoniuk, I., Quaini, F., Nadal-Ginard, B., Bodine, D.M., Leri, A., and Anversa, P. 2001b. Mobilized bone marrow cells repair the infarcted heart, improving function and survival. Proc. Natl. Acad. Sci. 98: 10344-10349.

Orphanides, G. and Reinberg, D. 2002. A unified theory of gene expression. Cell 108: 439-451.

Pandur, P., Lasche, M., Eisenberg, L.M., and Kuhl, M. 2002. Wnt-11 activation of a non-canonical Wnt signalling pathway is required for cardiogenesis. Nature 418: 636-641.

Passier, R., Zeng, H., Frey, N., Naya, F.J., Nicol, R.L., McKinsey, T.A., Overbeek, P., Richardson, J.A., Grant, S.R., and Olson, E.N. 2000. CaM kinase signaling induces cardiac hypertrophy and activates the MEF2 transcription factor in vivo. J. Clin. Invest. 105: 1395-1406.

Pasumarthi, K.B. and Field, L.J. 2002. Cardiomyocyte cell cycle regulation. Circ. Res. 90: 1044-1054.

Pittenger, M.F., Mackay, A.M., Beck, S.C., Jaiswal, R.K., Douglas, R., Mosca, J.D., Moorman, M.A., Simonetti, D.W., Craig, S., and Marshak, D.R. 1999. Multilineage potential of adult human mesenchymal stem cells. Science 284: 143-147.

Poolman, R.A., Li, J.M., Durand, B., and Brooks, G. 1999. Altered expression of cell cycle proteins and prolonged duration of cardiac myocyte hyperplasia in p27KIP1 knockout mice. Circ. Res. 85: 117-127.

Poss, K.D., Wilson, L.G., and Keating, M.T. 2002a. Heart regeneration in zebrafish. Science 298: $2188-2190$.

Poss, K.D., Nechiporuk, A., Hillam, A.M., Johnson, S.L., and Keating, M.T. 2002b. Mps1 defines a proximal blastemal proliferative compartment essential for zebrafish fin regeneration. Development 129: 5141-5149.

Ranganayakulu, G., Zhao, B., Dokidis, A., Molkentin, J.D., Olson, E.N., and Schulz, R.A. 1995. A series of mutations in the D-MEF2 transcription factor reveal multiple functions in larval and adult myogenesis in Drosophila. Dev. Biol. 171: 169181.

Reecy, J.M., Belaguli, N.S., and Schwartz, R.J. 1999. In Heart development (eds. R.P. Harvey and N. Rosenthal), pp. 273287. Academic Press, New York.

Reifers, F., Walsh, E.C., Leger, S., Stainier, D.Y., and Brand, M. 2000. Induction and differentiation of the zebrafish heart requires fibroblast growth factor 8 (fgf8/acerebellar). Development 127: 225-235.

Reinecke, H., Zhang, M., Bartosek, T., and Murry, C.E. 1999. Survival, integration, and differentiation of cardiomyocyte grafts: A study in normal and injured rat hearts. Circulation 100: 193-202.

Reinecke, H., Poppa, V., and Murry, C.E. 2002. Skeletal muscle stem cells do not transdifferentiate into cardiomyocytes after cardiac grafting. J. Mol. Cell. Cardiol. 34: 241-249.

Reiss, K., Cheng, W., Ferber, A., Kajstura, J., Li, P., Li, B., Olivetti, G., Homcy, C.J., Baserga, R., and Anversa, P. 1996. Overexpression of insulin-like growth factor- 1 in the heart is coupled with myocyte proliferation in transgenic mice. Proc. Natl. Acad. Sci. 93: 8630-8635.

Reiter, J.F., Alexander, J., Rodaway, A., Yelon, D., Patient, R., Holder, N., and Stainier, D.Y. 1999. Gata5 is required for the development of the heart and endoderm in zebrafish. Genes \& Dev. 13: 2983-2995.

Rentschler, S., Zander, J., Meyers, K., France, D., Levine, R., Porter, G., Rivkees, S.A., Morley, G.E., and Fishman, G.I. 2002. Neuregulin-1 promotes formation of the murine cardiac conduction system. Proc. Natl. Acad. Sci. 99: 1046410469.

Ries, L.A.G., Eisner, M.P., Kosary, C.L., Hankey, B.F., Miller,
B.A., Clegg, L., Mariotto, A., Fay, M.P., Feuer, E.J., and Edwards, B.K. 2003. SEER Cancer Statistics Review, 19752000, National Cancer Institute. Bethesda, MD, http://seer. cancer.gov/csr/1975_2000, with inescapable heart failure perhaps its most alarming element.

Riley, P., Anson-Cartwright, L., and Cross, J.C. 1998. The Hand 1 bHLH transcription factor is essential for placentation and cardiac morphogenesis. Nat. Genet. 18: 271-275.

Riley, P.R., Gertsenstein, M., Dawson, K., and Cross, J.C. 2000. Early exclusion of hand 1 -deficient cells from distinct regions of the left ventricular myocardium in chimeric mouse embryos. Dev. Biol. 227: 156-168.

Robbins, J., Gulick, J., Sanchez, A., Howles, P., and Doetschman, T.C. 1990. Mouse embryonic stem cells express cardiac myosin heavy chain genes during development in vitro. J. Biol. Chem. 265: 11905-11909.

Rosenthal, N. and Xavier-Neto, K. 2000. From the bottom of the heart: Anteroposterior decisions in cardiac muscle differentiation. Curr. Opin. Cell Biol. 12: 742-746.

Rothermel, B.A., McKinsey, T.A., Vega, R.B., Nicol, R.L., Mammen, P., Yang, J., Antos, C.L., Shelton, J.M., Bassel-Duby, R., Olson, E.N., et al. 2001. Myocyte-enriched calcineurin-interacting protein, MCIP1, inhibits cardiac hypertrophy in vivo. Proc. Natl. Acad. Sci. 98: 3328-3333.

Rottbauer, W., Saurin, A.J., Lickert, H., Shen, X., Burns, C.G., Wo, Z.G., Kemler, R., Kingston, R., Wu, C., and Fishman, M. 2002. Reptin and pontin antagonistically regulate heart growth in zebrafish embryos. Cell 111: 661-672.

Rudolph, K.L., Chang, S., Lee, H.W., Blasco, M., Gottlieb, G.J., Greider, C., and DePinho, R.A. 1999. Longevity, stress response, and cancer in aging telomerase-deficient mice. Cell 96: 701-712.

Rybkin, I.I., Markham, D.W., Yan, Z., Bassel-Duby, R., Williams, R.S., and Olson, E.N. 2003. Conditional expression of SV40 $\mathrm{T}$ antigen in mouse cardiomyocytes facilitates an inducible switch from proliferation to differentiation. J. Biol. Chem. 278: 15927-15934.

Sadoshima, J. and Izumo, S. 1995. Rapamycin selectively inhibits angiotensin II-induced increase in protein synthesis in cardiac myocytes in vitro. Potential role of $70-\mathrm{kD}$ S6 kinase in angiotensin II-induced cardiac hypertrophy. Circ. Res. 77: 1040-1052.

Sakai, T., Li, R.K., Weisel, R.D., Mickle, D.A., Jia, Z.Q., Tomita, S., Kim, E.J., and Yau, T.M. 1999. Fetal cell transplantation: A comparison of three cell types. J. Thorac. Cardiovasc. Surg. 118: 715-724.

Sano, M. and Schneider, M.D. 2003. Cyclins that don't cycle: Cyclin t/cyclin-dependent kinase-9 determines cardiac muscle cell size. Cell Cycle 2: 99-104.

Sano, M., Abdellatif, M., Oh, H., Xie, M., Bagella, L., Giordano, A., Michael, L.H., DeMayo, F.J., and Schneider, M.D. 2002. Activation and function of cyclin T-Cdk9 (positive transcription elongation factor-b) in cardiac muscle-cell hypertrophy. Nat. Med. 8: 1310-1317.

Schmelzle, T. and Hall, M.N. 2000. TOR, a central controller of cell growth. Cell 103: 253-262.

Schneider, V.A. and Mercola, M. 2001. Wnt antagonism initiates cardiogenesis in Xenopus laevis. Genes \& Dev. 15: 304-315.

Schneider, M.D., Gaussin, V., and Lyons, K.M. 2003. Tempting fate: BMP signals for cardiac morphogenesis. Cytokine Growth Factor Rev. 14: 1-4.

Schultheiss, T.M., Burch, J.B., and Lassar, A.B. 1997. A role for bone morphogenetic proteins in the induction of cardiac myogenesis. Genes \& Dev. 11: 451-462.

Schwartz, R.J. and Olson, E.N. 1999. Building the heart piece by 
piece: Modularity of cis-elements regulating Nkx2-5 transcription. Development 126: 4187-4192.

Seale, P., Asakura, A., and Rudnicki, M.A. 2001. The potential of muscle stem cells. Dev. Cell 1: 333-342.

Sepulveda, J.L., Belaguli, N., Nigam, V., Chen, C.Y., Nemer, M., and Schwartz, R.J. 1998. GATA-4 and Nkx-2.5 coactivate Nkx-2 DNA binding targets: Role for regulating early cardiac gene expression. Mol. Cell. Biol. 18: 3405-3415.

Sepulveda, J.L., Vlahopoulos, S., Iyer, D., Belaguli, N., and Schwartz, R.J. 2002. Combinatorial expression of GATA4, $\mathrm{Nkx} 2-5$, and serum response factor directs early cardiac gene activity. J. Biol. Chem. 277: 25775-2582.

Shake, J.G., Gruber, P.J., Baumgartner, W.A., Senechal, G., Meyers, J., Redmond, J.M., Pittenger, M.F., and Martin, B.J. 2002. Mesenchymal stem cell implantation in a swine myocardial infarct model: Engraftment and functional effects. Ann. Thorac. Surg. 73: 1919-1925.

Shi, Y., Katsev, S., Cai, C., and Evans, S. 2000. BMP signaling is required for heart formation in vertebrates. Dev. Biol. 224: 226-237.

Shin, C.H., Liu, Z.P., Passier, R., Zhang, C.L., Wang, D.Z., Harris, T.M., Yamagishi, H., Richardson, J.A., Childs, G., and Olson, E.N. 2002. Modulation of cardiac growth and development by HOP, an unusual homeodomain protein. Cell 110: $725-735$.

Shioi, T., McMullen, J.R., Kang, P.M., Douglas, P.S., Obata, T., Franke, T.F., Cantley, L.C., and Izumo, S. 2002. Akt/protein kinase B promotes organ growth in transgenic mice. Mol. Cell. Biol. 22: 2799-2809.

Shioi, T., McMullen, J.R., Tarnavski, O., Converso, K., Sherwood, M.C., Manning, W.J., and Izumo, S. 2003. Rapamycin attenuates load-induced cardiac hypertrophy in mice. Circulation 107: 1664-1670.

Soonpaa, M.H., Koh, G.Y., Klug, M.G., and Field, L.J. 1994. Formation of nascent intercalated disks between grafted fetal cardiomyocytes and host myocardium. Science 264: 98-101.

Srivastava, D. 2001. Genetic assembly of the heart: Implications for congenital heart disease. Annu. Rev. Physiol. 63: 451469.

Srivastava, D. and Olson, E.N. 2000. A genetic blueprint for cardiac development. Nature 407: 221-226.

Srivastava, D., Cserjesi, P., and Olson, E.N. 1995. A subclass of bHLH proteins required for cardiac morphogenesis. Science 270: 1995-1999.

Srivastava, D., Thomas, T., Lin, Q., Kirby, M.L., Brown, D., and Olson, E.N. 1997. Regulation of cardiac mesodermal and neural crest development by the bHLH transcription factor, dHAND. Nat. Genet. 16: 154-160.

Stamm, C., Westphal, B., Kleine, H.D., Petzsch, M., Kittner, C., Klinge, H., Schumichen, C., Nienaber, C.A., Freund, M., and Steinhoff, G. 2003. Autologous bone-marrow stem-cell transplantation for myocardial regeneration. Lancet 361: 4546.

Strauer, B.E., Brehm, M., Zeus, T., Kostering, M., Hernandez, A., Sorg, R.V., Kogler, G., and Wernet, P. 2002. Repair of infarcted myocardium by autologous intracoronary mononuclear bone marrow cell transplantation in humans. Circulation 106: 1913-1918.

Stuckmann, I., Evans, S., and Lassar, A.B. 2003. Erythropoietin and retinoic acid, secreted from the epicardium, are required for cardiac myocyte proliferation. Dev. Biol. 255: 334-349.

Sucov, H.M., Dyson, E., Gumeringer, C.L., Price, J., Chien, K.R., and Evans, R.M. 1994. RXR $\alpha$ mutant mice establish a genetic basis for vitamin A signaling in heart morphogenesis. Genes \& Dev. 8: 1007-1018.

Sugden, P.H. and Clerk, A. 1998. Regulation of mitogen-acti- vated protein kinase cascades in the heart. Adv. Enzyme Regul. 38: 87-98.

Tabin, C.J. and Vogan, K.J. 2003. A two-cilia model for vertebrate left-right axis specification. Genes \& Dev. 17: 1-6.

Takahashi, T., Kalka, C., Masuda, H., Chen, D., Silver, M., Kearney, M., Magner, M., Isner, J.M., and Asahara, T. 1999. Ischemia- and cytokine-induced mobilization of bone marrow-derived endothelial progenitor cells for neovascularization. Nat. Med. 5: 434-438.

Tanaka, M., Chen, Z., Bartunkova, S., Yamasaki, N. and Izumo, S. 1999. The cardiac homeobox gene Csx/Nkx2.5 lies genetically upstream of multiple genes essential for heart development. Development 126: 1269-1280.

Taylor, D.A., Atkins, B.Z., Hungspreugs, P., Jones, T.R., Reedy, M.C., Hutcheson, K.A., Glower, D.D., and Kraus, W.E. 1998. Regenerating functional myocardium: Improved performance after skeletal myoblast transplantation. Nat. Med. 4: 929-933.

Thattaliyath, B.D., Livi, C.B., Steinhelper, M.E., Toney, G.M., and Firulli, A.B. 2002. HAND1 and HAND2 are expressed in the adult-rodent heart and are modulated during cardiac hypertrophy. Biochem. Biophys. Res. Commun. 297: 870-875.

Thomas, T., Kurihari, H., Yamagishi, H., Kurihara, Y., Yazaki, Y., Olson, E.N., and Srivastava, D. 1998. A signaling cascade involving endothelin-1, dHAND and Msx1 regulates development of neural crest-derived branchial arch mesenchyme. Development 125: 3005-3014.

Toma, C., Pittenger, M.F., Cahill, K.S., Byrne, B.J., and Kessler, P.D. 2002. Human mesenchymal stem cells differentiate to a cardiomyocyte phenotype in the adult murine heart. Circulation 105: 93-98.

Tonissen, K.F., Drysdale, T.A., Lints, T.J., Harvey, R.P., and Krieg, P.A. 1994. XNkx-2.5, a Xenopus gene related to Nkx2.5 and tinman: Evidence for a conserved role in cardiac development. Dev. Biol. 162: 325-328.

Tran, C.M. and Sucov, H.M. 1998. The RXR $\alpha$ gene functions in a non-cell-autonomous manner during mouse cardiac morphogenesis. Development 125: 1951-1956.

Tse, H.F., Kwong, Y.L., Chan, J.K., Lo, G., Ho, C.L., and Lau, C.P. 2003. Angiogenesis in ischaemic myocardium by intramyocardial autologous bone marrow mononuclear cell implantation. Lancet 361: 47-49.

Tzahor, E. and Lassar, A.B. 2001. Wnt signals from the neural tube block ectopic cardiogenesis. Genes \& Dev. 15: 255-260.

Vega, R.B., Rothermel, B.A., Weinheimer, C.J., Kovacs, A., Naseem, R.H., Bassel-Duby, R., Williams, R.S., and Olson, E.N. 2003. Dual roles of modulatory calcineurin-interacting protein 1 in cardiac hypertrophy. Proc. Natl. Acad. Sci. 100: 669-674.

Verfaillie, C.M. 2002. Adult stem cells: Assessing the case for pluripotency. Trends Cell Biol. 12: 502-508.

Walters, M.J., Wayman, G.A., and Christian, J.L. 2001. Bone morphogenetic protein function is required for terminal differentiation of the heart but not for early expression of cardiac marker genes. Mech. Dev. 100: 263-273.

Wang, D., Chang, P.S., Wang, Z., Sutherland, L., Richardson, J.A., Small, E., Krieg, P.A., and Olson, E.N. 2001. Activation of cardiac gene expression by myocardin, a transcriptional cofactor for serum response factor. Cell 105: 851-862.

Wang, Z., Wang, D.-Z., Pipes, G.C.T., and Olson, E.N. 2003. Myocardin is a master regulator of smooth muscle gene expression. Proc. Natl. Acad Sci. 100: 7129-7134.

Wobus, A.M., Guan, K.M., Jin, S., Wellner, M.C., Rohwedel, J., Ji, G.J., Fleischmann, B., Katus, H.A., Hescheler, T., and Franz, W.M. 1997. Retinoic acid accelerates embryonic stem cell-derived cardiac differentiation and enhances develop- 
Olson and Schneider

ment of ventricular cardiomyocytes. I. Mol. Cell. Cardiol. 29: 1525-1539.

Wu, H., Lee, S.H., Gao, J., Liu, X., and Iruela-Arispe, M.L. 1999. Inactivation of erythropoietin leads to defects in cardiac morphogenesis. Development 126: 3597-3605.

Xavier-Neto, J., Neville, C.M., Shapiro, M.D., Houghton, L., Wang, G.F., Nikovits Jr., W., Stockdale, F.E., and Rosenthal, N. 1999. A retinoic acid-inducible transgenic marker of sinoatrial development in the mouse heart. Development 126: $2677-2687$.

Xu, C., Liguori, G., Adamson, E.D., and Persico, M.G. 1998. Specific arrest of cardiogenesis in cultured embryonic stem cells lacking Cripto-1. Dev. Biol. 196: 237-247.

Xu, C., Liguori, G., Persico, M.G., and Adamson, E.D. 1999. Abrogation of the Cripto gene in mouse leads to failure of postgastrulation morphogenesis and lack of differentiation of cardiomyocytes. Development 126: 483-494.

Yamagishi, H., Yamagishi, C., Nakagawa, O., Harvey, R.P., Olson, E.N., and Srivastava, D. 2001. The combinatorial activities of Nkx2.5 and dHAND are essential for cardiac ventricle formation. Dev. Biol. 239: 190-203.

Yang, J., Rothermel, B., Vega, R.B., Frey, N., McKinsey, T.A., Olson, E.N., Bassel-Duby, R., and Williams, R.S. 2000. Independent signals control expression of the calcineurin inhibitory proteins MCIP1 and MCIP2 in striated muscles. Circ. Res. 87: E61-68.

Yelon, D., Ticho, B., Halpern, M.E., Ruvinsky, I., Ho, R.K., Silver, L.M., and Stainier, D.Y. 2000. The bHLH transcription factor hand2 plays parallel roles in zebrafish heart and pectoral fin development. Development 127: 2573-2582.

Yoshida, T., Sinha, S., Dandre, F., Wamhoff, B.R., Hoofnagle, M.H., Kremer, B.E., Wang, D.Z., Olson, E.N., and Owens, G.K. 2003. Myocardin is a key regulator of CArG-dependent transcription of multiple smooth muscle marker genes. Circ. Res. 92: 856-864.

Zaffran, S. and Frasch, M. 2002. Early signals in cardiac development. Circ. Res. 91: 457-469.

Zhang, D., Gaussin, V., Taffet, G.E., Belaguli, N.S., Yamada, M., Schwartz, R.J., Michael, L.H., Overbeek, P.A., and Schneider, M.D. 2000. TAK1 is activated in the myocardium after pressure overload and is sufficient to provoke heart failure in transgenic mice. Nat. Med. 6: 556-563.

Zhang, C.L., McKinsey, T.A., Chang, S., Antos, C.L., Hill, J.A., and Olson, E.N. 2002. Class II histone deacetylases act as signal-responsive repressors of cardiac hypertrophy. Cell 110: 479-488.

Zhao, Y.Y., Sawyer, D.R., Baliga, R.R., Opel, D.J., Han, X., Marchionni, M.A., and Kelly, R.A. 1998. Neuregulins promote survival and growth of cardiac myocytes. Persistence of ErbB2 and ErbB4 expression in neonatal and adult ventricular myocytes. J. Biol. Chem. 273: 10261-10269. 


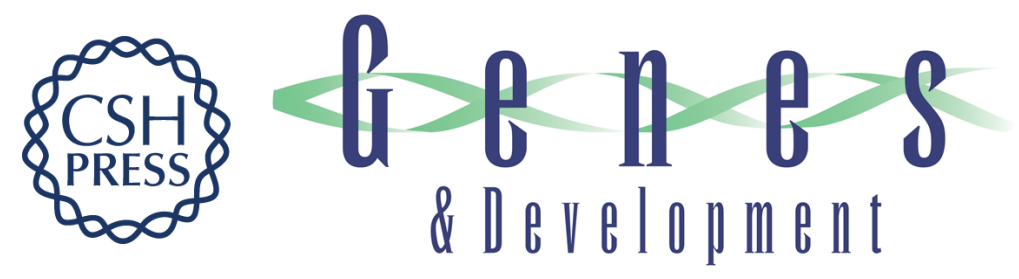

\section{Sizing up the heart: development redux in disease}

Eric N. Olson and Michael D. Schneider

Genes Dev. 2003, 17:

Access the most recent version at doi:10.1101/gad.1110103

References This article cites 206 articles, 98 of which can be accessed free at: http://genesdev.cshlp.org/content/17/16/1937.full.html\#ref-list-1

License

Email Alerting Receive free email alerts when new articles cite this article - sign up in the box at the top Service right corner of the article or click here.

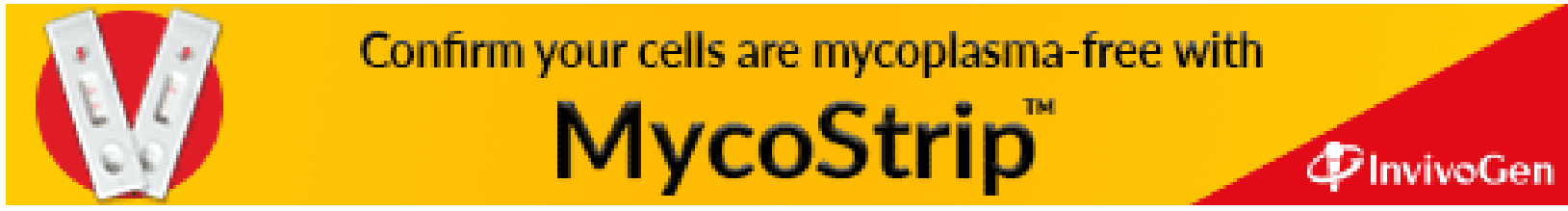

